\title{
Human bladder cancer cells undergo cisplatin-induced apoptosis that is associated with p53-dependent and p53-independent responses
}

\author{
EUMORPHIA G. KONSTANTAKOU ${ }^{1}$, GERASSIMOS E. VOUTSINAS ${ }^{2}$, PANAGIOTIS K. KARKOULIS ${ }^{2}$, \\ GERASIMOS ARAVANTINOS $^{3}$, LUKAS H. MARGARITIS ${ }^{1}$ and DIMITRIOS J. STRAVOPODIS ${ }^{1}$
}

${ }^{1}$ Department of Cell Biology and Biophysics, Faculty of Biology, University of Athens, Panepistimiopolis, Zografou 157 84;
${ }^{2}$ Laboratory of Environmental Mutagenesis and Carcinogenesis, Institute of Biology, NCSR 'Demokritos', 15310 Athens;
${ }^{3}$ 3rd Clinic of Pathology-Oncology, 'Agioi Anargyroi' Oncology Hospital, Ilion 13122 Athens, Greece

Received March 30, 2009; Accepted May 27, 2009

DOI: 10.3892/ijo_00000353

\begin{abstract}
Cisplatin is a first-line chemotherapeutic agent and a powerful component of standard treatment regimens for several human malignancies including bladder cancer. DNA$\mathrm{Pt}$ adducts produced by cisplatin are mainly responsible for cellular toxicity and induction of apoptosis. Identification of the mechanisms that control sensitivity to cisplatin is central to improving its therapeutic index and to successfully encountering the acquired resistance frequently emerging during therapy. In the present study, using MTT-based assays, Western blotting and semi-quantitative RT-PCR, we examined the apoptosis-related cellular responses to cisplatin exposure in two human urinary bladder cancer cell lines characterized by different malignancy grade and $p 53$ genetic status. Both RT4 (grade I; wild-type p53) and T24 (grade III; mutant $p 53$ ) cell types proved to be vulnerable to cisplatin apoptotic activity, albeit in a grade-dependent and drug dose-specific manner, as demonstrated by the proteolytic
\end{abstract}

Correspondence to: Dr Dimitrios J. Stravopodis, Department of Cell Biology and Biophysics, Faculty of Biology, University of Athens, Panepistimiopolis, Zografou 15784 Athens, Greece E-mail: dstravop@biol.uoa.gr

Abbreviations: BSA, bovine serum albumin; cisplatin, cisdiamminedichloroplatinum (II)/cis-[ $\left.\mathrm{PtCl}_{2}\left(\mathrm{NH}_{3}\right)_{2}\right] / \mathrm{CDDP}$; DMEM, Dulbecco's modified Eagle's medium; ECL, enhanced chemiluminescence; FBS, fetal bovine serum; GAPDH, glyceraldehyde 3phosphate dehydrogenase; HRP, horseradish peroxidase; Hsp90, heat shock protein 90; IAPs, inhibitor of apoptosis proteins; MMLV, Moloney murine leukemia virus; MTT, 3-(4,5-dimethylthiazol-2yl)-2,5-diphenyltetrazolium bromide; PARP, poly(ADP-ribose) polymerase; PBS, phosphate-buffered saline; PMSF, phenylmethylsulfonyl fluoride; RT-PCR, reverse transcription-polymerase chain reaction; SDS, sodium dodecyl sulfate; TBS-T, Tris-buffered saline-Tween-20

Key words: apoptosis, bladder, cancer, chemotherapy, cisplatin, $\mathrm{p} 53$, resistance processing profiles of Caspase-8, Caspase-9, Caspase-3, and the Caspase repertoire characteristic substrates PARP and Lamin A/C, as well. The differential resistance of RT4 and T24 cells to cisplatin-induced apoptosis was associated with an RT4-specific phosphorylation (Ser15; Ser392) pattern of p53, together with structural amputations of the Akt and XIAP anti-apoptotic regulators. Furthermore, cisplatin administration resulted in a Granzyme B-mediated proteolytic cleavage of Hsp90 molecular chaperone, exclusively occurring in RT4 cells. To generate functional networks, expression analysis of a number of genes, including Bik, Bim, Bcl-2, FAP-1, Fas, FasL, TRAIL, Puma, Caspase-10, ATP7A, ATP7B and $M R P 1$, was performed, strongly supporting the role of $\mathrm{p} 53-$ dependent and p53-independent transcriptional responses in cisplatin-induced apoptosis of bladder cancer cells.

\section{Introduction}

With its incidence continuing to increase, bladder cancer is classified among the five most common malignancies in industrialized countries (1). Forming a worldwide estimate over one million patients, bladder cancer is clearly considered a significant public health issue around the world (2). The three main types of cancer affecting bladder are transitional cell carcinoma (TCC), squamous cell carcinoma (SCC) and adenocarcinoma (ADC), with TCC representing $>90 \%$ of all bladder cancers. Four clinically distinct entities of TCC have been recognized: superficial, papillary tumors (Ta and T1), carcinoma in situ (Tis), muscle-invasive tumors (T2-T4) and advanced disease, involving extra-pelvic nodal or distant metastasis $(3,4)$. Metastatic TCC demonstrates a moderate sensitivity to chemotherapy while a significant variation in patient survival rates and activity levels of individual regimens has been observed (5).

Cisplatin-based combination chemotherapy protocols, such as MVAC (methotrexate-vinblastine-adriamycin-cisplatin), constituted for a number of years standard treatment of patients with advanced (or metastatic) urothelial bladder cancer. However, due to the MVAC-induced systemic toxicity, novel therapeutic schemes containing different drug-coctails have been developed, with cisplatin occupying a central position 
among them (i.e., GC: gemcitabine-cisplatin) (3-5). Cisplatin is structured by a platinum atom surrounded by two ammonium and two chloride atoms in the cis position of a horizontal plane (6-8). Upon entering a cell, cisplatin becomes activated through an aquation process characterized by the loss of chloride ions and gain of two water molecules. This positively charged derivative can subsequently interact with a variety of cellular components bearing nucleophilic sites, including, among others, cytoskeletal microfilaments, membrane phospholipids, proteins, RNA and DNA. However, it is generally accepted that DNA is the preferential and cytotoxic target for cisplatin (7-9). The platinum atom of cisplatin forms covalent bonds to the N-7 atoms of the imidazole rings of guanosine and adenosine that reside in the major groove of the double helix, thus resulting in the formation of DNA adducts. These are typified in six major categories characterized by $1,2-\mathrm{d}(\mathrm{GpG})$ intrastrand crosslinks, 1,2-d(ApG) intrastrand crosslinks, $1,3-\mathrm{d}(\mathrm{GpXpG})$ intrastrand crosslinks, G-G interstrand crosslinks, monofunctional crosslinks and intermolecular DNAprotein crosslinks, all inducing prominent, albeit variable, DNA structural distortions (6-10).

Cisplatin-mediated damage of genomic DNA causes severe cell cycle perturbation and arrest at certain checkpoints, while in the absence of adequate repair the affected cells undergo programmed cell death via an apoptosis process. The specific apparatus that triggers apoptosis in response to cisplatin should not only be able to detect genome detriments, but also to determine whether damage is sufficiently severe to be lethal $(6,7,9-12)$. Transduction of DNA-damage signals induced by cisplatin critically modulates, among others, the apoptosis-promoting activity of p53 transcription factor and the cell survival-protecting function of Akt serine/threonine kinase $(6,9,13-19)$. Interestingly, mutations in the $p 53$ genetic locus have been strongly implicated in bladder cancer development, whereas there has been controversy regarding the role of p53 in cellular resistance to cisplatin $(3,4,6,20)$. The relationship between p53 status and cisplatin cytotoxicity should depend on tumor cell type, activation of specific signaling pathways, the presence of additional genetic alterations and other p53-independent determinants (6).

In this context, here, we have studied the cisplatininduced apoptotic responses of two human urinary bladder cancer cell lines, mainly distinguished by their disparate grade of malignancy. Our data demonstrate that the differential resistance of the p53-proficient RT4 cell line (grade I) and p53-deficient T24 cell line (grade III) to cisplatinmediated apoptosis is tightly associated with p53-dependent and p53-independent cellular activities. The critical role of p53, Akt, XIAP and Hsp90 proteins was evaluated, while the expression profile of several genes involved in apoptosis and resistance to the drug was also examined.

\section{Materials and methods}

Drugs and reagents. Cisplatin was purchased from EBEWE Pharma Ges.m.b.H. Nfg.KG (Unterach, Austria). The antibodies recognizing Caspase-3 (\#9662), Caspase-8 (\#9746), Caspase-9 (\#9502), PARP (\#9542), Lamin A/C (\#2032), ßActin (\#4968), p53 (\#9282), Phospho-p53-Ser15 (\#9284), Phospho-p53-Ser392 (\#9281), Akt (\#9272), Phospho-Akt-
Ser473 (\#9271), XIAP (\#2042) and Granzyme B (\#4275) were obtained from Cell Signaling Technology Inc. (Hertfordshire, UK), whereas the antibody against Hsp90 (SC-13119) was purchased from Santa Cruz Biotechnology Inc. (California, USA). ECL Western blotting reagents were supplied by GE Healthcare-Amersham (Buckinghamshire, UK). Gene-specific oligonucleotide primers were synthesized by Metabion (Martinsried, Germany) and Operon (California, USA). All the other chemicals were obtained from Sigma-Aldrich (MO, USA), Fluka (Hannover, Germany) and AppliChem $\mathrm{GmbH}$ (Darmstadt, Germany).

Cells and culture conditions. The established cell lines from TCC human bladder cancer, RT4 (grade I) and T24 (grade III) were obtained from the European Collection of Animal Cell Cultures (Salisbury, UK) and Professor John R. Masters (Prostate Cancer Research Centre, Institute of Urology, UCL, UK), respectively. Both cell lines were maintained in DMEM containing 10\% FBS, $2 \mathrm{mM}$ L-glutamine, $100 \mathrm{U} / \mathrm{ml}$ penicillin, $100 \mu \mathrm{g} / \mathrm{ml}$ streptomycin, $1 \mathrm{mM}$ sodium pyruvate, $50 \mathrm{mM}$ sodium bicarbonate and $1 \mathrm{x}$ non-essential amino acids at $37^{\circ} \mathrm{C}$ and $5 \% \mathrm{CO}_{2}$. Contrary to the wild-type $p 53$ genotype of RT4 cells, the T24 cell line contains a p53 mutant allele that carries an in-frame deletion of the TAC triplet encoding tyrosine 126 $\left(Y^{126}\right)(21,22)$. All cell culture media and reagents were purchased from Biochrom AG (Berlin, Germany).

Cell viability assay. RT4 and T24 cells were seeded at densities of 20000 cells/well into 48-well flat-bottomed plates, treated with or without cisplatin $(1,10$ and $50 \mu \mathrm{g} / \mathrm{ml})$ and incubated for $24 \mathrm{~h}$ at $37^{\circ} \mathrm{C}$ in a humidified atmosphere of $95 \%$ air and $5 \% \mathrm{CO}_{2}$. Cell viability was assessed by MTT assay (23). Two hundred microliters of $0.5 \mathrm{mg} / \mathrm{ml}$ MTT solution (SigmaAldrich) was added to each well. After $4 \mathrm{~h}$ of incubation, the generated formazan crystals were dissolved in $200 \mu \mathrm{l}$ of isopropanol. The absorbance of each well was measured in an ELISA microtiter plate reader (Dynatech MR5000; Dynatech Laboratories, USA) at $570 \mathrm{~nm}$, using $630 \mathrm{~nm}$ as a wavelength of reference. Absorbance obtained by untreated cells was rated as $100 \%$ of cell survival. Each MTT assay was repeated three times, using three wells per experimental condition.

Western blotting. At $24 \mathrm{~h}$ after cisplatin treatment (1 and $10 \mu \mathrm{g} / \mathrm{ml}$ ), the RT4 and T24 cells were harvested, washed twice with PBS and solubilized in lysis buffer [15 mM Tris-base, $75 \mathrm{mM} \mathrm{NaCl}, 5 \mathrm{mM} \mathrm{Na} \mathrm{EDTA}_{2}, 50 \mathrm{mM} \mathrm{Na} \mathrm{P}_{2} \mathrm{O}_{7}$, $50 \mathrm{mM} \mathrm{NaF}, 0.5 \mathrm{mM} \mathrm{Na}_{3} \mathrm{VO}_{4}, 2 \%$ Triton $\mathrm{X}-100,10 \%$ glycerol and $2 \mathrm{mM}$ PMSF (pH 7.6 at $4^{\circ} \mathrm{C}$ )]. After centrifugation at $12000 \mathrm{~g}$ for $20 \mathrm{~min}$ at $4^{\circ} \mathrm{C}$, the supernatant was collected as the total protein extract and stored at $-30^{\circ} \mathrm{C}$. Protein concentrations were measured using the Bradford-type protein assay (Bio-Rad, USA). Equal amounts of protein (40 $\mu \mathrm{g})$ were separated by SDS-polyacrylamide gel electrophoresis and electrotransferred to nitrocellulose membrane (Schleicher and Schuell GmbH, Germany). Each membrane was blocked with 5\% non-fat dry milk (or 5\% BSA where required) in TBS-T [20 mM Tris- $\mathrm{HCl}$ (pH 7.6), $137 \mathrm{mM} \mathrm{NaCl}$ and $0.2 \%$ Tween-20] for $2 \mathrm{~h}$ at room temperature and subsequently incubated with primary antibody $(1: 1500)$ for $16 \mathrm{~h}$ at $4^{\circ} \mathrm{C}$. 
Table I. Gene names, forward (F) and reverse (R) primer sequences, molecular sizes (bp) of the obtained PCR products and PCR conditions (temperature and number of cycles) for the herein studied genes critically associated with cisplatin-induced apoptosis and drug resistance of human bladder cancer cells.

\begin{tabular}{|c|c|c|c|c|}
\hline Gene name & Primer sequence & $\begin{array}{l}\text { Length of PCR } \\
\text { product (bp) }\end{array}$ & $\begin{array}{l}\text { Temperature } \\
\left({ }^{\circ} \mathrm{C}\right)\end{array}$ & $\begin{array}{c}\text { Number of } \\
\text { cycles }\end{array}$ \\
\hline 1. $B i k$ & $\begin{array}{l}\text { F: 5'-CTG TAT GAG CAG CTC CTG G-3' } \\
\text { R: 5'-GAT GTC CTC AGT CTG GTC G-3' }\end{array}$ & 252 & 55 & 30 \\
\hline 2. Bim & $\begin{array}{l}\text { F: 5'-TGT GAC AAA TCA ACA CAA ACC C-3' } \\
\text { R: 5'-AGT CGT AAG ATA ACC ATT CGT G-3' }\end{array}$ & 230 & 57 & 30 \\
\hline 3. $B c l-2$ & $\begin{array}{l}\text { F: 5'-TGT GGC CTT CTT TGA GTT CG-3' } \\
\text { R: 5'-AGC AGA GTC TTC AGA GAC AG-3' }\end{array}$ & 222 & 55 & 30 \\
\hline 4. $F A P-1$ & $\begin{array}{l}\text { F: 5'-CAG ATG GAA GTA TAG CCT TG-3' } \\
\text { R: 5'-TAG ATG GAC TTT CAC TGG AG-3' }\end{array}$ & 228 & 53 & 30 \\
\hline 5. GAPDH & $\begin{array}{l}\text { F: 5'-TGG TAT CGT GGA AGG ACT CAT GAC-3' } \\
\text { R: 5'-ATG CCA GTG AGC TTC CCG TTC AGC-3' }\end{array}$ & 189 & 55 & 28 \\
\hline 6. Fas & $\begin{array}{l}\text { F: 5'-GGA TGA ACC AGA CTG CGT G-3' } \\
\text { R: 5'-CTG CAT GTT TTC TGT ACT TCC-3' }\end{array}$ & 371 & 55 & 30 \\
\hline 7. FasL & $\begin{array}{l}\text { F: 5'-CTC TGG AAT GGG AAG ACA CC-3' } \\
\text { R: 5'-ACC AGA GAG AGC TCA GAT ACG-3' }\end{array}$ & 325 & 57 & 40 \\
\hline 8. TRAIL & $\begin{array}{l}\text { F: 5'-TGG CTA TGA TGG AGG TCC AG-3' } \\
\text { R: 5'-GTT GCC ACT TGA CTT GCC AG-3' }\end{array}$ & 249 & 57 & 30 \\
\hline 9. Puma & $\begin{array}{l}\text { F: 5'-CAG ACT GTG AAT CCT GTG CT-3' } \\
\text { R: 5'-ACA GTA TCT TAC AGG CTG GG-3' }\end{array}$ & 251 & 55 & 35 \\
\hline 10. Caspase-10 & $\begin{array}{l}\text { F: 5'-CAT AGG ATT GGT CCC CAA CA-3' } \\
\text { R: 5'-CTT GAT ACG ACT CGG CTT CC-3' }\end{array}$ & 500 & 55 & 32 \\
\hline 11. $A T P 7 A$ & $\begin{array}{l}\text { F: 5'-GCC TCT GAC ACA AGA AAC TG-3' } \\
\text { R: 5'-GCT ATT ACT ACC AAC GGC TC-3' }\end{array}$ & 246 & 55 & 30 \\
\hline 12. $A T P 7 B$ & $\begin{array}{l}\text { F: 5'-GCT GAT TGG AAA CCG TGA GT-3' } \\
\text { R: 5'-ATT GCG ATC ATC CCA CAG AG-3' }\end{array}$ & 144 & 55 & 30 \\
\hline 13. $M R P 1$ & $\begin{array}{l}\text { F: 5'-ACC TGG AAA CGG ACG ACC T-3' } \\
\text { R: 5'-TAC TCC TGG ATT TCT CCT TTG-3' }\end{array}$ & 142 & 55 & 32 \\
\hline 14. CTRI & $\begin{array}{l}\text { F: 5'-CCT TCT CAC CAT CAC CCA AC-3' } \\
\text { R: 5'-CTT GTG ACT TAC GCA GCA GG-3' }\end{array}$ & 238 & 57 & 30 \\
\hline
\end{tabular}

Immunoreactivity was detected by sequential incubation with HRP-conjugated secondary antibody $(1: 2000)$ and ECL reagents (24). Data were obtained from three different experiments, one of which is illustrated in the present study.

Semi-quantitative RT-PCR analysis. RT4 and T24 cells were treated with the indicated doses of cisplatin for $24 \mathrm{~h}(0,1$ and $10 \mu \mathrm{g} / \mathrm{ml}$ ) and total RNA was extracted with the TRIzol reagent, according to manufacturer's instructions (Invitrogen, USA). One microgram of RNA was reverse transcribed in $20-\mu 1$ reaction volume containing an oligo-d(T) primer
(Invitrogen) and the MMLV reverse transcriptase (Invitrogen). The resulting cDNA was subsequently amplified by semiquantitative PCR with the Biometra T3000 thermocycler (Goettingen, Germany), using 10 pmole of each forward and reverse cDNA-specific primer in a final volume of $25 \mu \mathrm{l}$. The PCR products were separated by agarose gel electrophoresis following standard procedures (25). The gene-specific names, the forward $(\mathrm{F})$ and reverse $(\mathrm{R})$ primer sequences, the molecular size of the amplified fragments, the annealing temperatures $(\mathrm{Ta})$ and the number of cycles performed for all the examined genes are summarized in Table I. Ampli- 
RT4

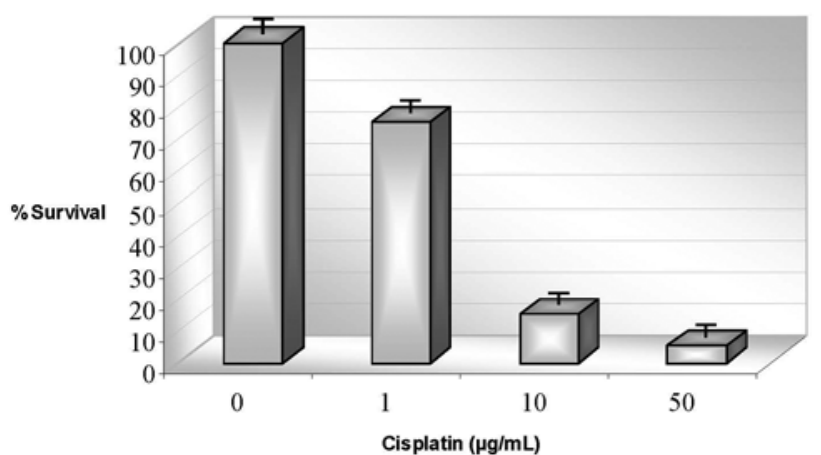

T24

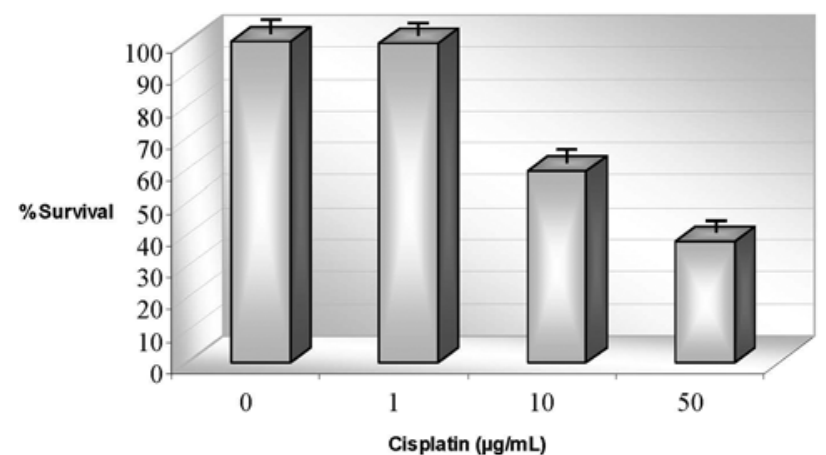

Figure 1. Grade-specific and dose-dependent cytotoxicity induced by exposure of RT4 (grade I) and T24 (grade III) human urinary bladder cancer cell lines to cisplatin for $24 \mathrm{~h}$, as determined using the MTT assay. T24 were undoubtedly more resistant to the drug activity than RT4 cells. Each drug concentration was tested in three individual wells, while each different experiment was repeated three times. Bars (two-dimensional) denote standard deviation values.

fications were normalized to $G A P D H$, which was used as a gene of reference. Data were collected from three different experiments, one of which is shown here.

\section{Results}

Cytotoxic effects of cisplatin against bladder cancer cells. The cytotoxic activity of cisplatin on the survival profiles of RT4 and T24 cell lines was determined by MTT assay (23). Treatment with cisplatin for $24 \mathrm{~h}$ markedly decreased the viability of RT4 and T24 cells in a dose-dependent manner. The survival rates of RT4 cells in the presence of 1,10 and $50 \mu \mathrm{g} / \mathrm{ml}$ cisplatin were averaged $75.4,15.23$ and $5.41 \%$, respectively. T24 cells demonstrated significant resistance to drug administration, as clearly documented by the 99.4 , 59.47 and $37.9 \%$ corresponding (mean) survival percentages (Fig. 1). The grade-specific response to cisplatin likely reflects the distinct genetic background of RT4 and T24 cells (i.e., p53 status) and their ability to differentially regulate the cell death process.

Grade-dependent apoptosis induced by cisplatin. Due to the strong cytotoxicity of $50 \mu \mathrm{g} / \mathrm{ml}$ cisplatin when administered to RT4 cells (Fig. 1), severely affecting protein and RNA extract yield, and in an effort to adopt clinically relevant drug doses, all the following treatments were carried out using 1 and $10 \mu \mathrm{g} / \mathrm{ml}$ of cisplatin concentration. After drug administration in both RT4 and T24 cells, the three major apoptotic components Caspase-8, Caspase- 9 and Caspase- 3 were specifically processed, resulting in the formation of active proteases, howbeit exempting Caspase- 8 in T24, as clearly revealed by a Western blotting approach. A similar cleavage profile was detected for PARP and Lamin A/C nuclear proteins, which represent characteristic substrates of the mature Caspase repertoire (Fig. 2). The extent of apoptotic response of different cell types to various drug concentrations could be reliably assessed by a quantified proportion of cleaved [C; (i.e., 17 and $19 \mathrm{kDa}$ for Caspase-3)] to precursor [P; (i.e., $35 \mathrm{kDa}$ for Caspase-3)] protein forms. Therefore, by comparing the $\mathrm{C} / \mathrm{P}$ respective ratios of $\mathrm{RT} 4$ and T24 cells, for all the examined apoptotic mediators, it is unambiguously concluded that T24 are significantly more resistant to cisplatin-induced apoptosis than RT4 cells. Even though the higher drug dose $(10 \mu \mathrm{g} / \mathrm{ml})$ is the effective one regarding proteolytic processing of all the examined proteins, Caspase- 8 is the only component being cleaved at the lower cisplatin concentration $(1 \mu \mathrm{g} / \mathrm{ml})$ exclusively in RT4 cells, thus corroborating their enhanced sensitivity to the drug. Moreover, the absence of the Caspase- $818 \mathrm{kDa}$ fragment in $\mathrm{T} 24$, but not in RT4 cells, treated with $10 \mu \mathrm{g} / \mathrm{ml}$ cisplatin (Fig. 2 and data not shown) likely reflects a T24-specific hindrance in the formation of a mature protease and an activation impairment of the cognate membrane death receptormediated apoptotic pathway $(12,26)$.

Cisplatin-mediated induction and phosphorylation of p53. Since p53 protein constitutes one of the most critical regulators of DNA damage-induced apoptosis and is frequently associated with chemoresistance in human cancers $(6,13-15,18)$, we sought to evaluate the role of p53 in cisplatin-mediated apoptosis of bladder cancer cells. Lysates derived from control and cisplatin-treated RT4 and T24 cells were subjected to Western blotting, using specific antibodies against total and phosphorylated p53. As shown in Fig. 3, administration of 1 and $10 \mu \mathrm{g} / \mathrm{ml}$ cisplatin in RT4 cells resulted in a strong induction of total and phosphorylated p53 protein levels. Serine residues at positions 15 and 392 (Ser15 and Ser392) were effectively phosphorylated in an RT4-specific manner, thus supporting a role of wild-type p53 in cisplatin cytotoxicity against bladder cancer. Moreover, the higher drug dose $(10 \mu \mathrm{g} / \mathrm{ml})$ appeared to enhance $\mathrm{p} 53$ protein instability, as documented by the formation of low molecular weight cleaved forms. In contrast, T24 cells remained almost unresponsive to cisplatin treatment, with an extremely weak upregulation of p53 phosphorylation at Ser15 and an undetectable profile of Ser392 phosphorylation induction and total protein level increase (Fig. 3). In toto, the obtained RT4 and T24 distinct patterns strongly indicate the essential role of $\mathrm{Y}^{126}$ in $\mathrm{p} 53$ protein (the missing tyrosine residue in T24 cells), regarding its activity and function under DNA damaging conditions $(21,22)$. 


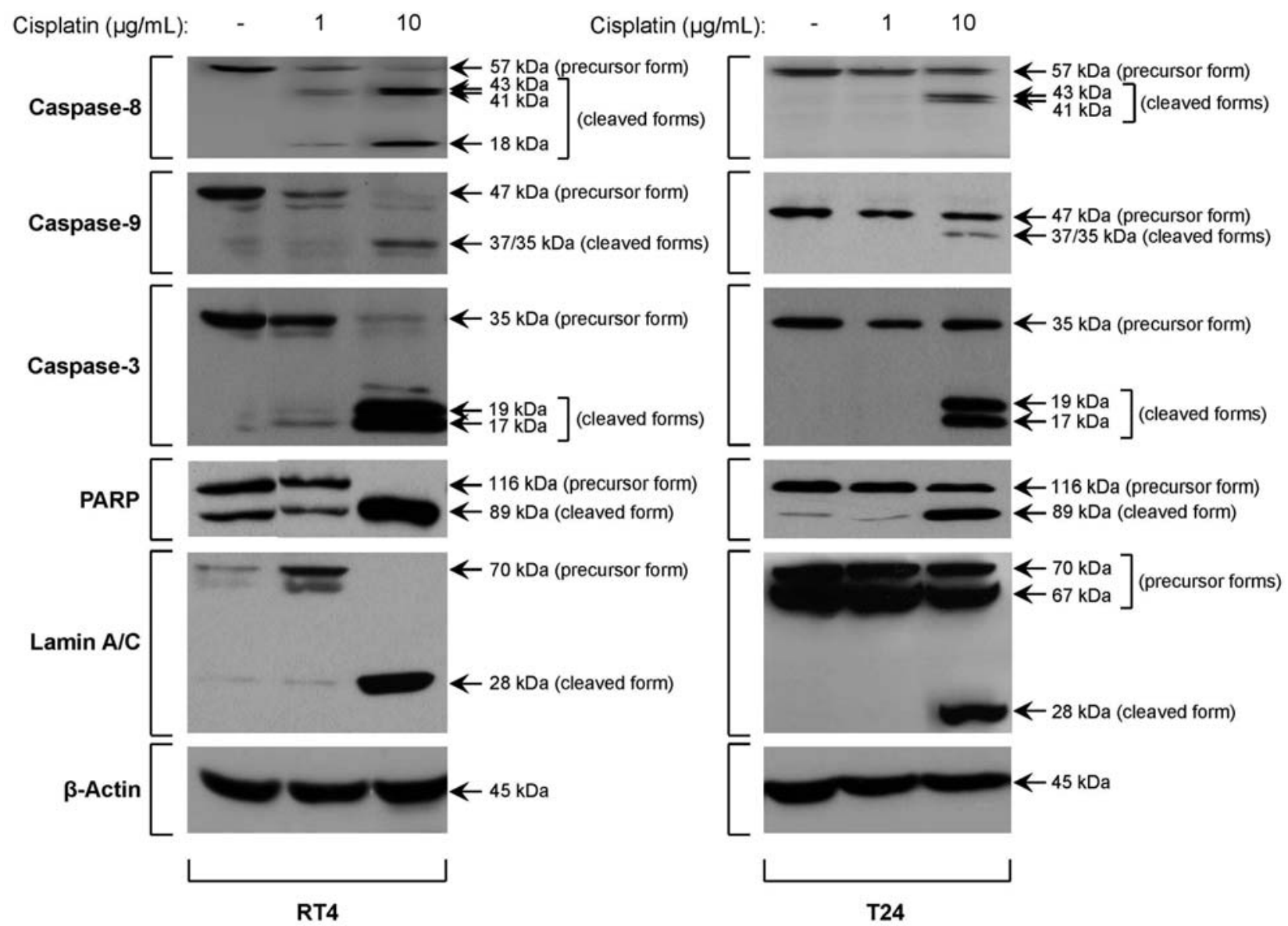

Figure 2. Activation of apoptosis after cisplatin administration, for 24 h, in RT4 and T24 human bladder cancer cells, as evinced by Western blotting. The drug induced a higher dose-dependent cleavage of Caspase-8 (also processed in the RT4 cells treated with the lower drug concentration), Caspase-9 and Caspase-3 family members, and the Caspase repertoire representative substrates PARP and Lamin A/C, as well, in both cell types. However, by comparing the C/P respective ratios for all the examined proteins, a significant relative resistance of T24 cells to cisplatin-mediated apoptosis was unambiguously recognized. Human $\beta$-Actin was used as a protein of reference.

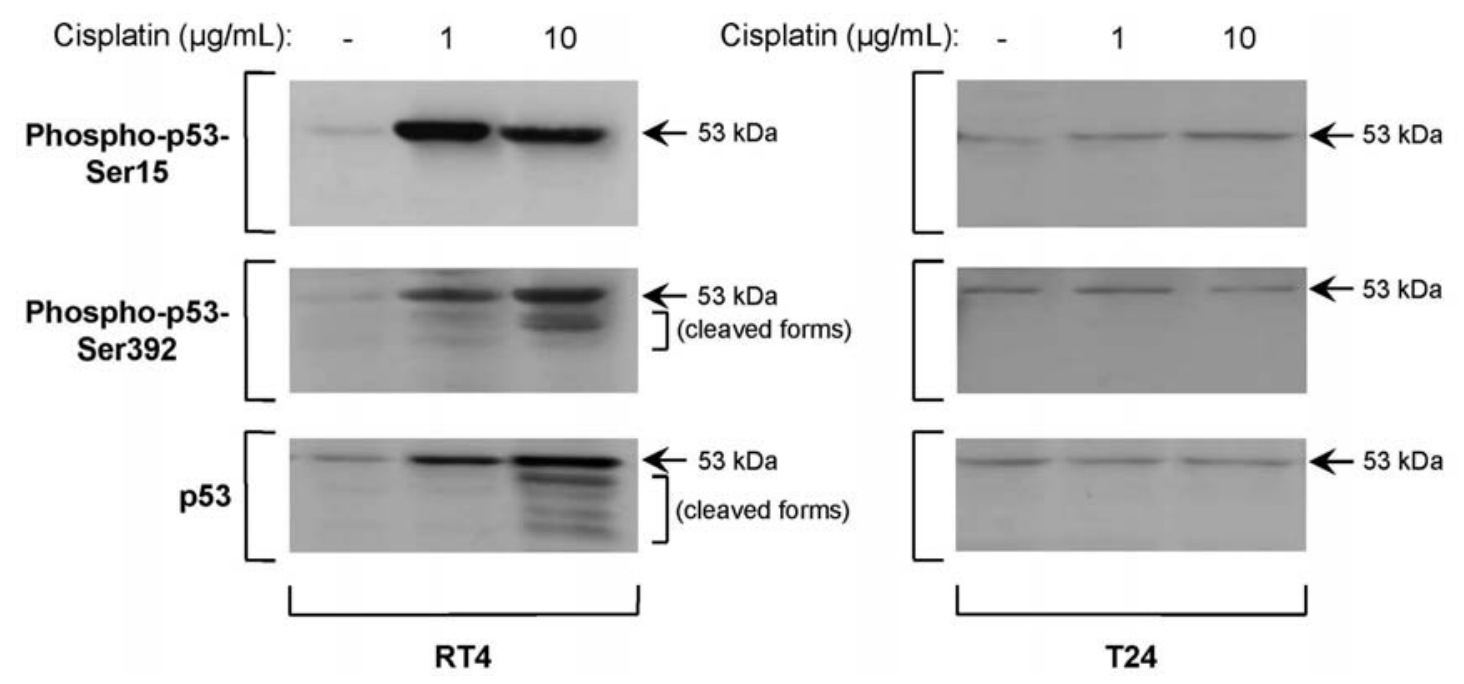

Figure 3. Cisplatin-induced accumulation and serine phosphorylation of wild-type p53 protein (left arrows), but not its mutant counterpart (right arrows), in human bladder cancer cells, as demonstrated by Western blotting. Both drug doses (1 and $10 \mu \mathrm{g} / \mathrm{ml})$ were able to strongly activate the mechanisms controlling p53 protein levels and phosphorylation events at Ser15 and Ser392 exclusively in RT4 (wild-type p53), but not in T24 (mutant p53) cells. Brackets denote the cleaved forms of the wild-type $\mathrm{p} 53$ protein.

Deregulation of Akt and XIAP signaling integrity by cisplatin. It has been previously suggested that alterations in p53dependent apoptosis are critically involved in Akt-mediated chemoresistance $(6,14,18)$. Thus, the role of Akt serine/ threonine kinase and its anti-apoptotic substrate XIAP $(6,16)$ in bladder cancer cells undergoing apoptosis after cisplatin 

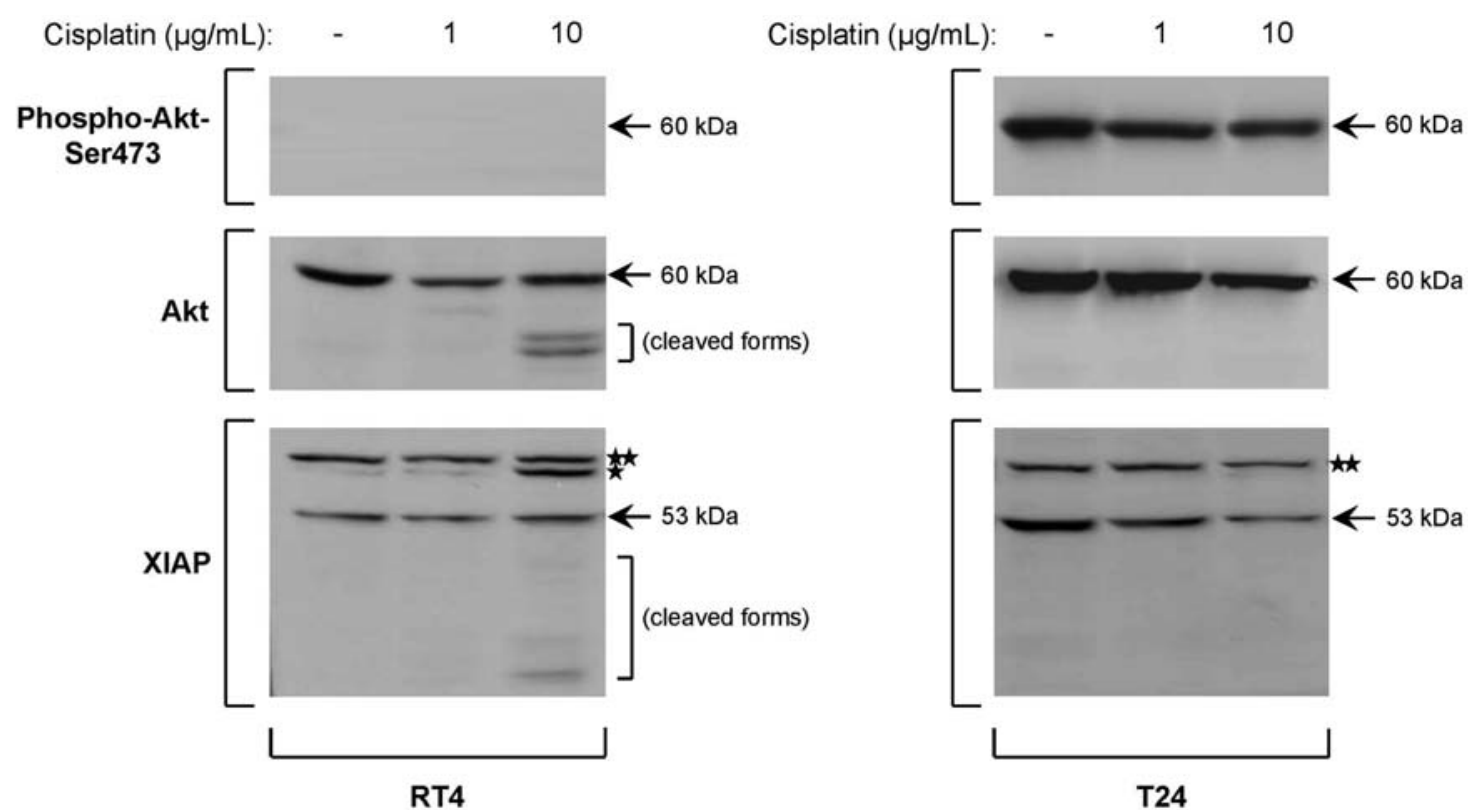

RT4

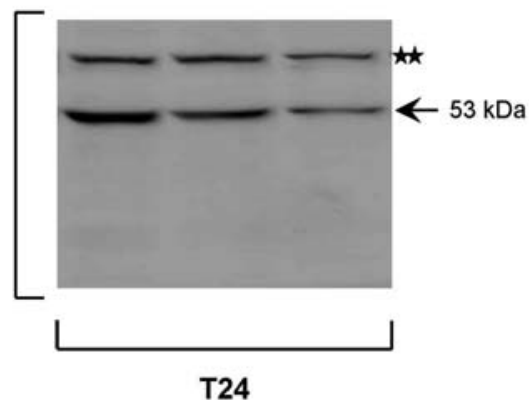

Figure 4. Grade-dependent structural amputation or degradation of the Akt and XIAP anti-apoptotic mediators after exposure of human bladder cancer cells to cisplatin, as shown by Western blotting. In contrast to T24, where a drug dose-dependent decrease of XIAP protein levels was detected, the RT4 cells treated for $24 \mathrm{~h}$ with the higher drug dose were characterized by the generation of Akt and XIAP proteolytically processed forms (brackets) that could somehow interfere with the functional activities of their respective uncleaved counterparts (arrows). Interestingly, the RT4 cells were void of the phosphorylated at Ser473 Akt form that was constitutively expressed in T24 cells, albeit moderately diminished upon cisplatin administration. Likewise, a modest reduction of total Akt protein levels was also observed in T24 (and RT4) cells after their treatment with the higher drug dose. Notably, the $1 \mu$ g/ml cisplatin could also lower the total Akt protein content specifically in RT4 but not T24 cells. One asterisk, a likely ubiquitinated form of XIAP; two asterisks, a high molecular weight XIAP-like protein of unknown function.

treatment (Fig. 2) was examined through a Western blotting approach (Fig. 4). In contrast to RT4 cells, T24 were characterized by strongly upregulated levels of phosphorylated Akt on a serine residue at position 473 (Ser473), which could be tightly associated with the different malignancy grade of the two cell lines. The RT4-specific absence of a constitutively activated Akt form, combined together with the generation of two low molecular weight (35 and $40 \mathrm{kDa}$, approximately) Akt cleaved protein fragments in RT4, but not in T24 cells, after $10 \mu \mathrm{g} / \mathrm{ml}$ cisplatin administration, presumably operating as dominant negative or 'squelching' isoforms, could justify the enhanced chemoresistance of T24 to cisplatin cytotoxic activity (Figs. 1, 2 and 4).

Consistent with the observed chemosensitivity profile, the XIAP anti-apoptotic mediator was shown to be cleaved into low molecular weight fragments, with a prominent moiety of $20 \mathrm{kDa}$, specifically in RT4 cells treated with $10 \mu \mathrm{g} / \mathrm{ml}$ cisplatin. The $\sim 90 \mathrm{kDa}$ protein band, exclusively detected in these cell lysates, likely represents a ubiquitinated form of XIAP, thus indicating the grade-specific activation of a general ubiquitination mechanism targeting proteins to proteasome for degradation $(16,27)$. The highest molecular weight band could comprise a XIAP-like homologue, whose functional importance remains to be determined. However, in T24 cells, a drug dose-dependent reduction of XIAP expression levels was observed, mainly characterized by a complete absence of protein fragmentation and ubiquitination signs (Fig. 4).

Cisplatin-induced cleavage of Hsp90 by Granzyme B. Since Hsp90 critically regulates the conformational maturation and stability of p53 and Akt proteins, and has recently emerged as a critical target for cancer therapy $(28,29)$, we attempted to examine its role in cisplatin-mediated apoptosis of bladder cancer cells through a Western blotting approach. As shown in Fig. 5, $10 \mu \mathrm{g} / \mathrm{ml}$ of cisplatin administration resulted in RT4-specific generation of a major Hsp90 cleaved form (a few minor ones could be also observed) with an approximate molecular weight of $65 \mathrm{kDa}$. This truncated protein product could presumably function in a dominantnegative manner against native Hsp90, thus inducing structural amputations of critical apoptosis mediators (i.e., p53, Akt and XIAP; Figs. 3 and 4), deregulating their functions and/or targeting them to proteasome for degradation (28).

It has been recently reported that Hsp90 represents a bona fide substrate of Granzyme B in vitro (30). Interestingly, the strong induction of Granzyme B protein levels after treatment of RT4 cells with $10 \mu \mathrm{g} / \mathrm{ml}$ cisplatin strongly suggests its essential in vivo role in the drug-mediated proteolytic cleavage of Hsp90. In contrast, T24 cells were characterized by a drug dose-dependent Granzyme B downregulation, clearly justifying their resistance to cisplatininduced Hsp90 proteolytic processing (Fig. 5).

Cisplatin-induced transcriptional responses implicated in mitochondria-mediated and membrane death receptoremanated apoptotic pathways. Among the majority of genes examined through a semi-quantitative RT-PCR approach, only the ones depicted in Table I displayed prominent alterations in transcriptional activity. Based on their gene expression profiles after drug administration, three major categories can be recognized: a) genes regulating apoptosis in p53-independent 

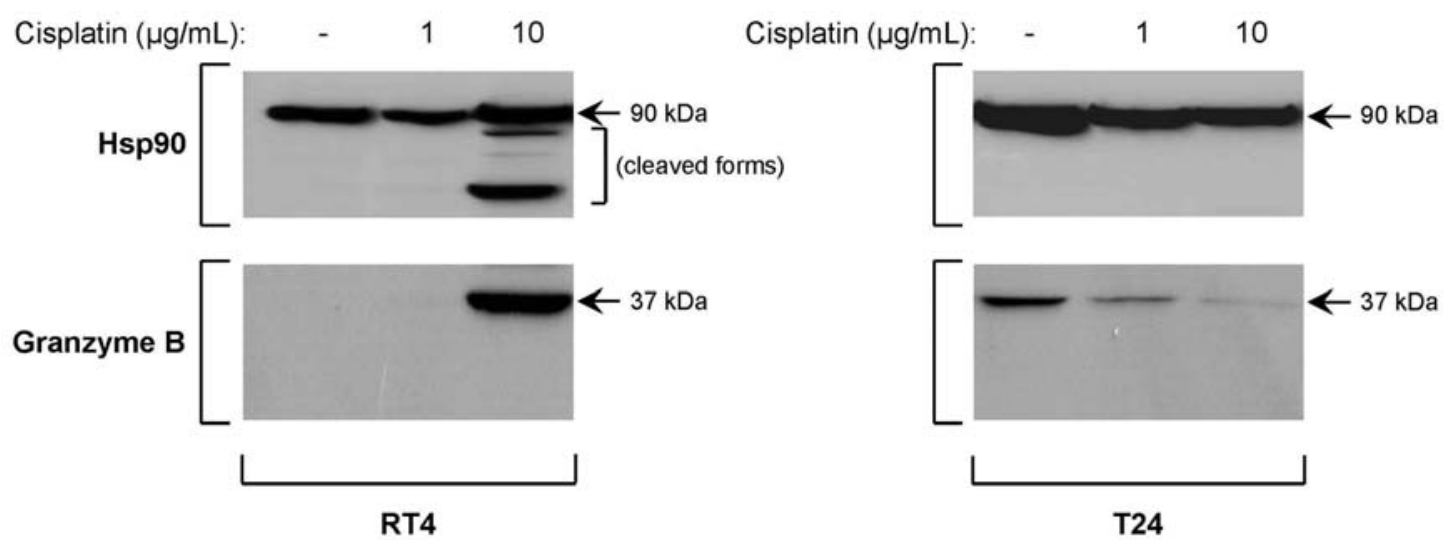

Figure 5. Granzyme B-mediated proteolytic cleavage of Hsp90 after cisplatin administration in human bladder cancer cells: a grade-specific process. As evinced by a Western blotting approach, the higher drug dose was able to significantly induce the Granzyme B protein expression levels and the generation of a major $\sim 65 \mathrm{kDa}$ Hsp90 cleaved fragment (the thick band at the bottom of the bracket) exclusively in RT4 (grade I) but not in T24 (grade III) cisplatin-treated cells.

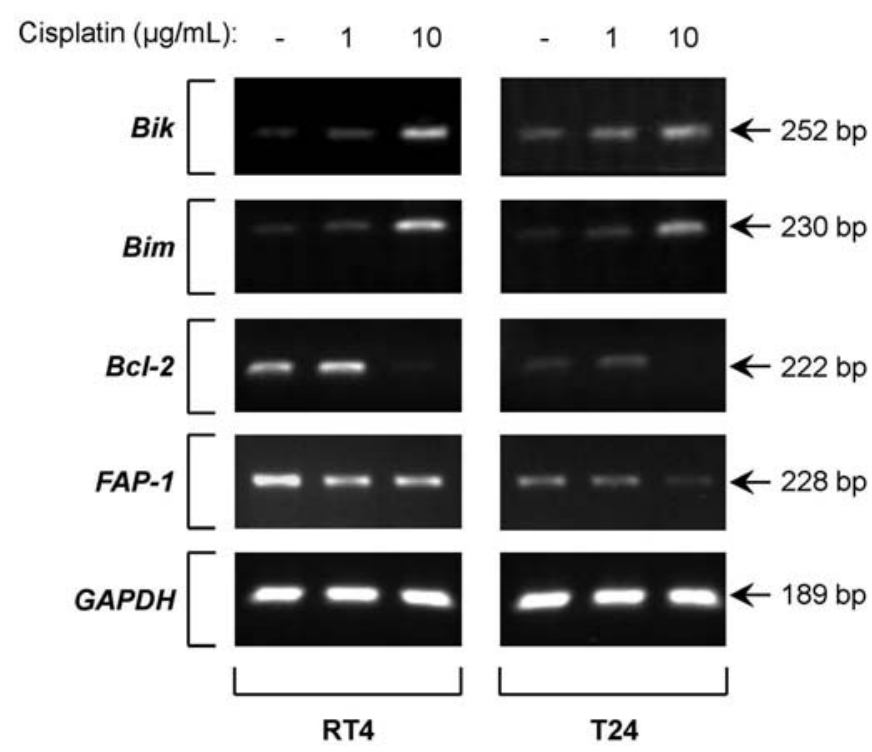

Figure 6. Expression analysis of apoptosis-related genes in cisplatin-exposed human bladder cancer cell lines (RT4 and T24), as demonstrated by semiquantitative RT-PCR. GAPDH was used as a gene of reference (also, for reactions illustrated in Figs. 7 and 8). The transcriptional responses to cisplatin activity of all the genes in this group proved to be regulated in p53-independent manner. The names of the genes are denoted on the left and the respective RT-PCR product sizes on the right.

manner (Fig. 6); b) p53-dependent genes involved in apoptosis (Fig. 7); and c) genes controlling cisplatin uptake and efflux regardless of p53 genetic status (Fig. 8).

As shown in Fig. 6, and using GAPDH as gene of reference, both Bik and Bim genes were notably upregulated in RT4 and T24 cells treated with $10 \mu \mathrm{g} / \mathrm{ml}$ cisplatin. On the contrary, $B c l-2$ expression levels were severely attenuated in the two cell lines examined, only in the higher drug dose, whereas $\mathrm{Bcl}-\mathrm{X}_{\mathrm{L}}$ and $\mathrm{Mcl}-\mathrm{l}$ gene activities remained unaffected under both cisplatin concentration conditions (data not shown). Given the pro-apoptotic role of Bik and Bim proteins and the anti-apoptotic activity of $\mathrm{Bcl}-2$ gene product, all critically regulating mitochondria physiology $(26,31)$, the obtained expression profiles strongly suggest a scenario of drug-induced apoptosis through perturbation of mitochondria function. The

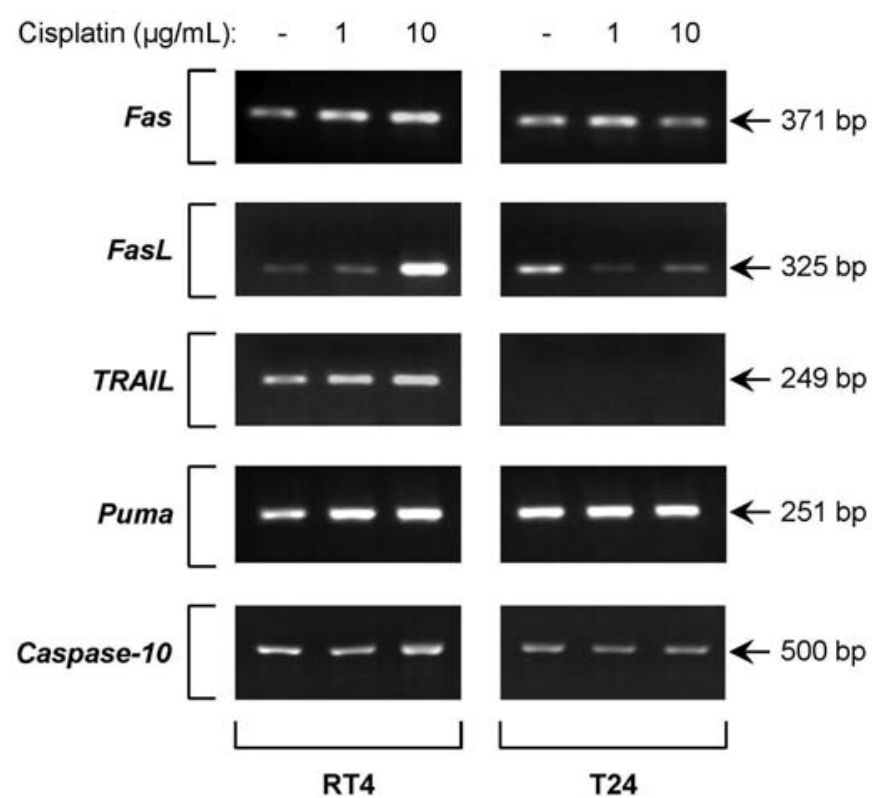

Figure 7. Expression profiles of genes involved in the regulation of apoptosis in human bladder cancer cells (RT4 and T24) treated for $24 \mathrm{~h}$ with different doses of cisplatin, as revealed by semi-quantitative RT-PCR. This group of genes was mainly characterized by p53-dependent responses to the drug, exempting, however, TRAIL, whose transcriptional silencing specifically in T24 cells could be attributed to distinct regulatory mechanisms (i.e., hypermethylation and/or hypoacetylation). The names of the examined genes are indicated on the left, while the molecular sizes, in base pairs (bp), of the respective RT-PCR fragments on the right.

p53-independent group of apoptotic genes also includes the FAP-1 (PTPL1) gene, coding for an inhibitor of Fas-mediated apoptosis $(32,33)$, which was significantly suppressed in grade-independent manner upon $10 \mu \mathrm{g} / \mathrm{ml}$ of cisplatin exposure (Fig. 6).

However, the membrane death receptor pathways seem to follow grade-specific activation profiles. After $10 \mu \mathrm{g} / \mathrm{ml}$ cisplatin administration, the pro-apoptotic genes Fas (APO-1/ CD95), FasL (CD95L), TRAIL and Caspase-10 were notably upregulated in RT4 cells, while in T24 they remained almost unaffected (albeit a slight downregulation could be observed for Fas and Caspase-10), exempting FasL and TRAIL. The 


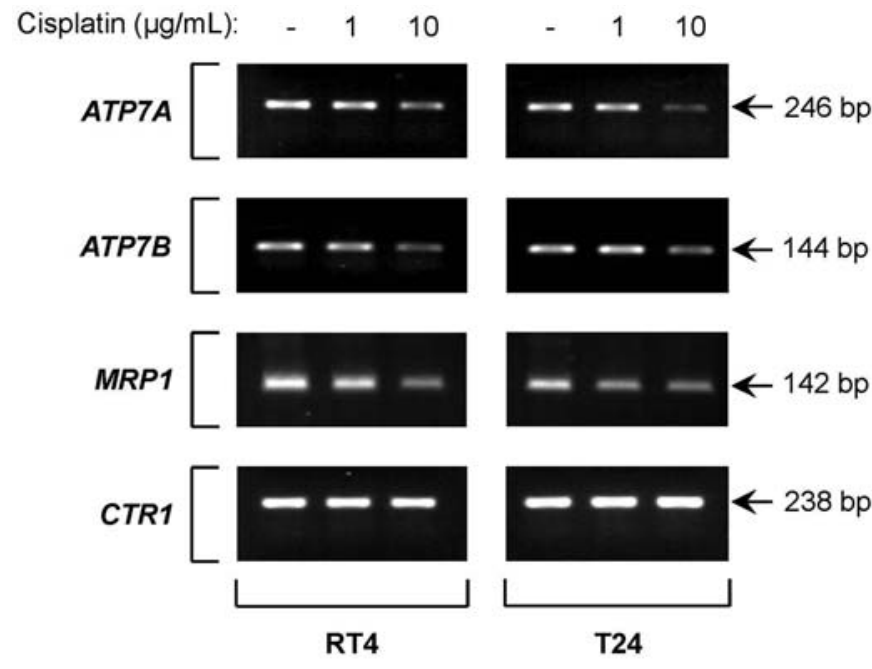

Figure 8. Examination of gene activity implicated in cisplatin trafficking after drug administration, for $24 \mathrm{~h}$, in human bladder cancer cells (RT4 and T24), as evinced by semi-quantitative RT-PCR. In contrast to CTRl function (critically involved in cisplatin uptake) that remained unaffected, the genes associated with drug efflux, $A T P 7 A, A T P 7 B$ and $M R P 1$, were notably downregulated in response to the higher dose of cisplatin, exhibiting p53independent expression profiles. The gene names are shown on the left and their respective RT-PCR product sizes on the right. significant drug-mediated reduction of FasL expression and the severe attenuation of TRAIL transcriptional activity in T24 cells indicate (together with Fas and Caspase-10 expression profiles) a high grade-specific functional impairment of distinct membrane death receptor systems regulating apoptosis (Fig. 7). Fas, FasL, Puma and Caspase-10 seem to be activated in p53-dependent fashion, in accordance with previous reports (34-37), whereas TRAIL must follow different, and likely p53-independent $(38,39)$, mechanisms controlling gene activity. Moreover, the RT4-specific induction of Puma after drug exposure strongly suggests an essential role of p53 target genes regulating mitochondria functions in cancer chemoresistance (Fig. 7) $(26,34)$.

p53-independent transcriptional activities associated with cisplatin trafficking. A major determinant of resistance to cisplatin is the diminished accumulation of the drug in a cell. Tolerance to cisplatin can be acquired by critically modulating, among others, the drug uptake and efflux cellular processes $(7,8,40,41)$. As shown in Fig. 8, the $A T P 7 A, A T P 7 B$ and $M R P 1$ ( $A B C C 1$ ) genes, encoding for membrane transporters decisively implicated in drug efflux $(7,8,42-46)$, were significantly downregulated in both cell types after $10 \mu \mathrm{g} / \mathrm{ml}$

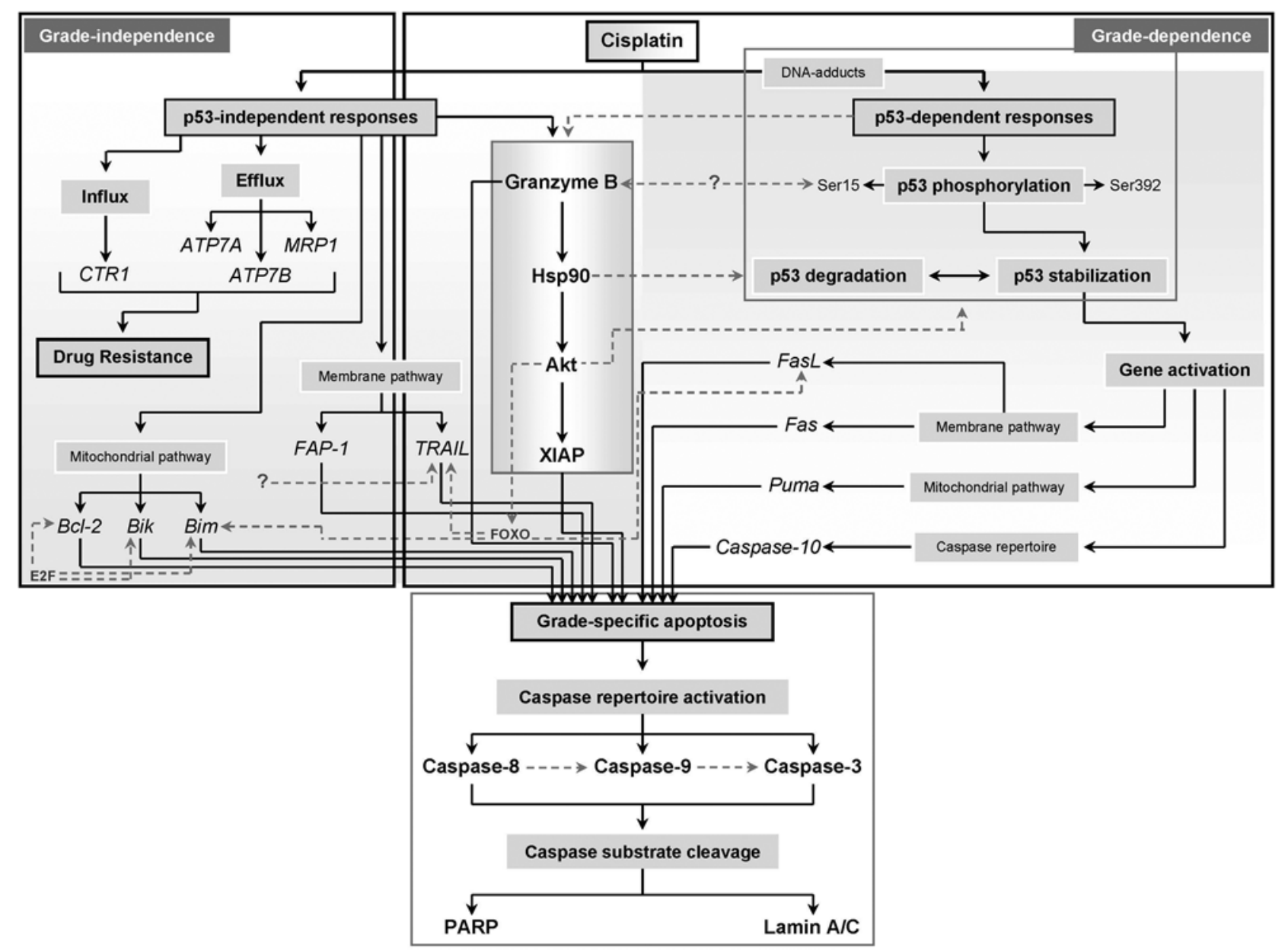

Figure 9. Schematic representation of an integrated molecular interaction map concisely depicting the herein examined regulators critically implicated in cisplatin-mediated apoptosis of RT4 and T24 human bladder cancer cells. Exposure to cisplatin results in the activation or repression of distinct p53-dependent and p53-independent mechanisms tightly related to induction of apoptosis and drug resistance. Proteins are denoted by bold-type fonts, whereas genes are represented by non-bold- and italic-type letters. 
cisplatin administration. In contrast, the expression levels of CTR1 (SLC31A1) gene, whose cognate protein regulates the import of cisplatin into a cell $(7,8,42,44,46)$, remained unaffected after drug exposure of both RT4 and T24 cells (Fig. 8). Therefore, cisplatin-induced toxicity in bladder cancer cells could be critically associated with p53-independent attenuation of certain drug efflux systems, eventually resulting in increased intracellular concentration of cisplatin.

\section{Discussion}

A major holdback to successful cancer chemotherapy is the, frequently observed, development of acquired resistance to drug exposure, which, thereby, renders tumor cell populations refractory to the applied regimens, eventually resulting to relapse of the disease. Cellular resistance to cisplatin cytotoxic activity seems to be a multifactorial process, mainly implemented through two broad types of mechanisms: a) prevention of the adequate amounts of drug from reaching and binding to the target DNA molecule, due to decreased cisplatin uptake, increased cisplatin efflux, upregulated detoxification and augmented DNA repair, and b) failure of cell death and increased survival, despite the drug-induced DNA damage, through severe deregulation of the apoptosis-related signaling pathways $(6-11,26,47,48)$.

Apoptosis is the prevailing response of cells to chemotherapeutic agents. Two major apoptotic pathways have been described for mammalian cells. The first one involves Caspase-8, which is activated through membrane death receptor-mediated extrinsic pathways, whereas the second one implicates mitochondria-emanated intrinsic pathways, being mainly characterized by activation of Caspase- 9 via Cytochrome c release into the cytosol and apoptosome formation (an Apaf-1- and ATP-dependent process). Subsequently, activated Caspase-3, as the major effector component of both pathways, initiates a program of proteolytic cleavages of critical cellular proteins, including PARP and Lamin A/C, eventually resulting to apoptosis $(6,26,33,47,49)$.

Indeed, here, we showed that exposure of human bladder cancer cells to cisplatin resulted in the generation of cleaved Caspase-8, Caspase-9, Caspase-3, PARP and Lamin A/C proteins, thus undoubtedly demonstrating the activation of apoptosis (Fig. 2). Both the membrane death receptor- and mitochondria-dependent pathways seemed to be engaged in the RT4 and T24 cell types, albeit in a grade-specific manner. Interestingly, through the comparison of their respective $\mathrm{C} / \mathrm{P}$ ratios, $\mathrm{T} 24$ proved to be significantly more resistant to cisplatin administration than RT4 cells, strongly corroborating their MTT assay-based differential cytotoxic responses (Fig. 1). Moreover, in contrast to the activation of Caspase- 8 even in the lower drug dose of RT4-treated cells, which unambiguously confirms their increased sensitivity to the drug, T24 were not only unable for a respective response, but they were also missing the $18 \mathrm{kDa}$ small fragment, likely implying an inability to form the mature and fully active tetramer of Caspase-8, and an attenuation of the Caspase-8mediated downstream signaling pathways. In agreement with our results, proteolytic processing and activation of initiator and effector Caspases have been also reported before in Jurkat T leukemia cells, MCF-7 breast cancer cells and human osteosarcoma (HOS) cells after cisplatin administration (6,49-51). Notably, cisplatin apoptotic activity in Jurkat T leukemia cells was shown to be independent of membrane death receptors, while mitochondria contribution was definitely required (49). However, depending on the cellular model system used, cisplatin-induced apoptosis could also involve certain Caspase-independent pathways, as it has been previously described for ovarian cancer cells and renal proximal tubular cells (RPTC) $(6,52,53)$. In toto, we reveal that clinically relevant doses of cisplatin can induce apoptosis in bladder cancer cells through the activation of Caspase repertoire, whereas relative tolerance to the drug can arise from downregulation of membrane death receptor-emanated apoptotic pathways.

p53 is a fundamental tumor suppressor protein that plays a crucial role in a variety of biological processes including cell-cycle arrest and induction of apoptosis in response to cellular stress $(6,54)$. Sensitivity to cisplatin has been tightly associated with the presence of wild-type p53 activity in a National Cancer Institute (NCI) collection of sixty human cancer cell lines $(6,55)$. Furthermore, tumor cells lacking functional p53 were more resistant to cisplatin than cells containing wild-type p53, but could be sensitized upon reconstitution with the proficient p53 protein $(6,56-58)$. Nevertheless, in certain cellular systems no or even negative correlation between response to cisplatin and p53 status has been previously observed. For example, in SaOS-2 osteosarcoma cells p53 activity was adequately tied in with increased resistance to cisplatin under low serum conditions, whereas the absence of p53 in testicular teratocarcinoma cells did not alter cellular sensitivity to the drug $(6,59,60)$.

We, herein, reveal that the grade-specific cytotoxic and apoptotic responses of RT4 and T24 human bladder cancer cells to cisplatin are tightly associated with the drug-induced functional activities of p53 protein (Fig. 3). It seems that the missing critical tyrosine $126\left(\mathrm{Y}^{126}\right)$ dramatically affects the molecular physiology of the p53 mutant protein, thus prohibiting its competence to be phosphorylated at Ser 15 and Ser392 target residues upon cisplatin exposure of T24 cells. Interestingly, certain p53 natural mutants from human tumors, harboring changes elsewhere from the decisive serine positions, such as $\left[\mathrm{Ile}^{237}\right] \mathrm{p} 53$ and $\left[\mathrm{Ala}^{143}\right] \mathrm{p} 53$, exhibit altered Ser15 and Ser392 phosphorylation profiles (61). In RT4 cells, the cisplatin-induced phosphorylation at Ser15 results in the structural stabilization and intracellular accumulation of p53 protein, by likely disrupting its interaction with the MDM2 negative regulator, which otherwise targets p53 for ubiquitin-mediated degradation. This stress signal-dependent increase in p53 half-life time from minutes to hours promotes distinct transcriptional programs tightly regulating apoptosis $(13,20,27,34,62,63)$. Alternatively, Ser15 phosphorylation could be implicated in promoting p53 interaction with B56 $\gamma$-PP2A phosphatase, thereby leading to Thr55 dephosphorylation and subsequent induction of p53 protein stabilization, as recently described (64). On the other hand, the cisplatin-mediated phosphorylation of the wild-type p53 at Ser392, exclusively observed in RT4 cells, should strongly potentiate its DNA binding activity through a putative stabilization mechanism of the p53 tetramer form $(13,65)$. Since MDM2 constitutes a bona fide p53 target gene $(13,20,34)$, the 
progressive accumulation of functional p53 upon cisplatin exposure could result in overproduction of MDM2 protein that acts as a ubiquitin ligase to effectively degrade p53 through proteasome targeting $(20,27,63)$, thus likely explaining the cleaved p53 forms detected in the higher drug dose (Fig. 3).

Although it remains to be determined, in RT4 cells, one (or more) of the ATM, ATR and DNA-PK kinases could be likely implicated in the cisplatin-induced phosphorylation of p53 at Ser15, whereas Ser392 phosphorylation might be implemented by one (or more) of the p38 MAPK, CDK9 and CK2 kinases (65-67). Accordingly, a role of ATR/Chk2 signaling in p53 activation and subsequent apoptosis has been recently demonstrated in cisplatin-treated renal cells, thereby further illuminating the drug-induced nephrotoxicity mechanisms (15). ATR contains a putative Akt phosphorylation site (RRRLSS), and as such its function could be strongly regulated by the activated Akt kinase (18). Indeed, in ovarian cancer cells, inhibition of functional Akt potentiated total and phosphorylated p53 contents upon cisplatin exposure, whereas its activation suppressed drug-mediated phosphorylation of p53 (18). Thus, an (indirect) inhibitory role of the activated Akt kinase in p53 [especially when mutated (i.e., in T24 cells)] phosphorylation status could be likely envisioned for bladder cancer cells undergoing cisplatin treatment. In the same study, it was also shown that cisplatin induced phosphorylation of numerous p53 residues in chemosensitive ovarian cancer cells, but not in their respective chemoresistant variants, thereby suggesting that altered p53 phosphorylation profiles may significantly contribute to the acquisition of drug resistance during therapy. Moreover, the p53 phosphorylation status at Ser15 after cisplatin administration has been severely compromised in a chemorefractory clone of the A2780 ovarian cancer cell line (13), whereas ionizing radiation, applied as another typical DNA damaging factor, induces apoptosis in bladder cancer cell lines in p53-dependent manner (22). However, the relative chemosensitivity of RT4 cells to cisplatin could not solely be attributed to the marked phosphorylation of wild-type p53 at Ser15 and Ser392, but additional determinants are required for the implementation of cisplatinmediated apoptosis in bladder cancer cells. This scenario is strongly supported: a) by the ability of T24 cells to undergo apoptosis, albeit relatively extenuated, after drug treatment, despite the absence of overproduced and functional p53 protein, and, vice versa, b) by the inability of phosphorylated p53 to promote robust apoptosis of RT4 cells under lower cisplatin concentration, as compared to the higher drug dose respective response. Nevertheless, when total and phosphorylated p53 protein together with its respective cleaved forms seem to exceed critical thresholds of intracellular concentrations (i.e., in the higher dose of cisplatin) a reinforced apoptotic process could likely occur (Fig. 3).

Several observations indicate that Akt can protect cells from apoptotic death induced by various stress stimuli, including cisplatin $(6,47)$. Inactivation of Akt by ectopic expression of its negative regulator PTEN in tumor cells enhances druginduced apoptosis, whereas transfection of constitutively active Akt in lung cancer cells reduces topotecan-mediated apoptosis $(47,68)$. Moreover, fibroblasts overexpressing Akt become chemorefractory to staurosporine and etoposide apoptotic activities $(47,69,70)$. During tumor development, Akt can be activated by a number of mechanisms, including downregulation of PTEN (a dual-specificity phosphatase), overactivation of the PI3K (PI-3 kinase) upstream (positive) signaling mediator, Akt gene amplification and acquisition of somatic mutations in Akt critical residues, such as the glutamic acid to lysine substitution at amino acid position 17 (E17K) that promotes cellular transformation and induces leukemia in mice $(47,71)$. Therefore, the constitutively phosphorylated at Ser473, and presumably active, Akt form could be essentially implicated in the highly malignant behavior of T24 cells and in their partial resistance to cisplatin apoptotic activity. In contrast, the absence of a functional Akt in RT4 cells must be tightly associated with their low grade of tumorigenic potency and enhanced sensitivity to the drug (Fig. 4). Interestingly, it has been previously reported that the Akt phosphorylation content is strongly correlated with the invasiveness of urothelial cell lines (72). In contrast to RT4, the highly invasive T24 cell line harbors a missense point mutation at codon 48 (substitution of Ile for Asn) in the, critical for enzymatic activity, $\alpha 2$ helix of the PTEN dualspecificity phosphatase (73). Thus, the putative reduction of Akt dephosphorylation due to PTEN functional impairment (73), along with the increased PI3K catalytic activity levels, as elsewhere assessed by the specific inhibitor LY294002 (72), could both reliably account for the strong and constitutive expression of the phosphorylated at Ser473, and consequently activated, Akt apoptotic regulator, exclusively in T24 cells (Fig. 4).

Even though the RT4 cells do not express any phosphorylated at Ser473 Akt form, the generation of Akt and XIAP cleaved fragments could critically contribute to the higher drug dose-induced apoptosis. In ovarian cancer cells, XIAP can be phosphorylated at Ser87 by Akt, being, thereby, stabilized through inhibition of both its (XIAP) auto-ubiquitination and cisplatin-mediated ubiquitination activities $(6,16)$. It seems that XIAP degradation is an important mechanism to regulate its intracellular steady-state functional levels and determine sensitivity to cisplatin exposure. The anti-apoptotic activity of XIAP is exerted through direct inhibition of Caspase-3 and Caspase-7, and modulation of the Bax/Cytochrome c pathway by blocking Caspase-9 (12,74). In ovarian cancer cells, XIAP overexpression is associated with reduced cisplatin-stimulated Caspase-3 activity and apoptosis, while downregulation of XIAP is considered as an effective mean to overcome chemoresistance in the same cells that express either endogenous or reconstituted wild-type p53 protein $(6,14,16,74,75)$. It seems that RT4 and T24 cell lines engage distinct mechanisms to regulate XIAP in response to cisplatin. Under the higher drug dose conditions, RT4 are characterized by cleaved XIAP forms (cleavage pattern), whereas in $\mathrm{T} 24$ a significant reduction of the unprocessed protein is observed (complete degradation pattern) (Fig. 4). Since a relatively similar grade-specific pattern can be recognized for Akt as well, a putative mechanism of an Akt-dependent phosphorylation of XIAP that is able to prevent cisplatin-induced XIAP cleavage could be rationally adopted for bladder cancer cells $(6,16)$. However, the constitutively active Akt form in T24 cells does not seem to protect XIAP from complete degradation that is mainly defined by 
the absence of cleaved fragments, but drug dose-dependent reduction of the unprocessed protein expression levels. Thus, XIAP might play a master regulatory role in cisplatininduced apoptosis of T24 cells. When XIAP intracellular protein levels drop off a certain threshold, the Caspase repertoire can not be any more efficiently inhibited and apoptosis is immediately activated $(74,75)$. On the other hand, the cleaved XIAP forms detected in drug-treated RT4 cells could not only abolish XIAP anti-apoptotic potential, but could also function as negative (or positive) regulators of several critical components suppressing (or promoting) cell death, including Akt. The RT4-specific XIAP cleaved pattern could be produced by either a ubiquitin-mediated process, likely associated with the higher molecular weight band exclusively detected in $10 \mu \mathrm{g} / \mathrm{ml}$ cisplatin (Fig. 4; one asterisk), or a Caspase-3-dependent mechanism, as previously demonstrated during Fas-stimulated apoptosis (76). Interestingly, it was previously shown that active Caspase- 3 was able to cleave Akt in vitro and this effect could be blocked by the cognate Caspase inhibitor (75). According to this model, the Akt cleaved forms could function in a dominant negative manner, thus inhibiting the endogenous Akt activity and consequently implying a role of the non-phosphorylated Akt in suppressing apoptosis of RT4 cells. Alternatively, these small forms might illegitimately interact with distinct apoptotic regulators, such as XIAP protein, through a 'squelching' process, sequentially excluding them from the molecular anti-apoptotic network and eventually rendering them susceptible to functional inhibition or degradation. In contrast, the phosphorylation of Akt at Ser473 seems to provide protection against cisplatin-mediated cleavage of both Akt and its target substrate XIAP $(6,14,16)$, therefore offering $\mathrm{T} 24$ cells the advantage of relative chemoresistance.

Similarly to ovarian cancer cells (14), the wild-type p53 function in RT4 cells is absolutely required for the cisplatin-induced apoptotic effects of Akt and XIAP structural amputations. However, in drug-treated T24 cells XIAP downregulation could be partly counterbalanced by the non-functional p53 and constitutively active Akt, thereby conferring certain levels of resistance to cisplatin apoptotic activity. Interestingly, in ovarian cancer cells, Akt was able to attenuate the cisplatin-induced mitochondrial p53 accumulation and p53-dependent release of Smac apoptotic protein [a known counteractor of IAPs, including XIAP (26)] into the cytosol, strongly desensitizing cells from drug cytotoxic action (17). Hence, the functional p53 status should be considered as a major determinant of the Akt- and XIAPmediated chemoresistance frequently acquired during bladder cancer therapy.

Beyond its genotoxic activity, cisplatin critically modulates Hsp90 function through direct binding to two distinct sites of the molecule. Cisplatin seems to induce a conformational change in the Hsp90 amino-terminal domain (Hsp90N), while it can also block the aggregation prevention activity of the Hsp90 carboxyl-terminal domain (Hsp90C) $(28,29,77)$. Given the potent chaperoning role of Hsp90 in conformational maturation and stability of several client proteins related to apoptosis $(28,29)$, the approximately $65 \mathrm{kDa}$ cleaved form of Hsp90 might be essentially implicated in the cisplatin-mediated structural amputations of $\mathrm{p} 53$, Akt and XIAP proteins, speci- fically observed in the RT4 drug-treated cells (Fig. 5). A plausible scenario could engage the putative dominant negative function of the $\sim 65 \mathrm{kDa}$ fragment to inhibit the structural integrity guarding activity of the Hsp90 unprocessed protein, thereby rendering distinct clients vulnerable to proteolytic cleavage and degradation. Interestingly, an oxidative stressmediated cleavage of Hsp90 has been recently shown to occur in K562 cells, severely disrupting Hsp90 chaperoning activity, strongly promoting Akt and Bcr-Abl (representative clients) degradation, and finally inducing apoptosis (78). Since Hsp90 can be proteolytically processed by certain apoptosis-stimulating agents, including cisplatin (present study), oxidative stress factors, arsenic-based compounds and doxorubicin (78-80), it must be considered as a central mediator of cytotoxic responses to various cellular insults. Based on the epitope recognizing specificity of the monoclonal antibody used here, which selectively binds to the Hsp90 carboxyl-terminal region, the site of the cleavage should be located close to the amino-terminal part of Hsp90. A very similar Hsp90 proteolytic profile has been also observed in K562 cells during oxidative stress and in RT4 cells after doxorubicin administration $(78,80)$.

Using the GraBCas algorithm, we were able to previously identify a putative Granzyme B (a serine protease) recognition and cleavage site in the amino acid sequence of both Hsp90 ( $\alpha$ and $\beta$ ) proteins, whereas no high probability binding motif for any Caspase family member could be recognized (80). In accordance, exposure of either K562 cells or recombinant Hsp90 protein to human Granzyme B resulted in the generation of Hsp90 cleaved fragments $(30,78)$, thereby indicating that Hsp90 comprises a bona fide substrate of Granzyme B in vitro. In RT4 cells, the drug-induced protein levels of Granzyme B seem to follow the same expression profile of the $\sim 65 \mathrm{kDa}$ truncated form, thus strongly supporting the crucial role of Granzyme B in proteolysis and downregulation of Hsp90 during cisplatin-mediated bladder cancer cell apoptosis (Fig. 5). Intriguingly, delivery of Granzyme B to melanoma cells (T1) resulted in the activation of ATM and p38 MAPK stress kinases and subsequent phosphorylation of p53 at Ser15 and Ser37 residues, providing insight into the functional relationship between Granzyme B and p53 during cellular disintegration (81). Therefore, the grade-dependent expression profile of Granzyme B in response to cisplatin administration might be functionally associated with the $p 53$ genetic status of RT4 and T24 cells. As such, when Granzyme B is overexpressed in RT4 cells, it could significantly contribute to p53 protein accumulation and phosphorylation, while its downregulation in T24 cells might hamper p53 (particularly when mutated) responses to cisplatin (Figs. 3 and 5). Furthermore, it seems that the cisplatin-mediated decrease of Granzyme B in T24 cells allows the protection of Hsp90 from proteolytic cleavage, thereby retaining the structural integrity of certain anti-apoptotic clients (i.e., Akt) under cisplatin exposure conditions, and eventually providing some degree of cellular resistance against them. Whether Granzyme B represents a bona fide target gene of the activated p53 protein is an interesting speculation that needs to be further explored (34).

Part of the DNA damage response can be coordinated, besides p53, by additional pathways of apoptosis guided 
by the E2F1 transcription factor $(82,83)$. After cisplatin exposure, E2F1 protein can be stabilized in the drug-treated cells by distinct mechanisms, including ATM-mediated serine phosphorylation, increased CDK2 kinase activity and, likely, P/CAF-induced lysine acetylation (83-86). Interestingly, the accumulation of E2F1 protein in mouse embryo fibroblasts (MEFs) following cisplatin treatment seems to occur independently of their p53 genetic status $(84,86)$. E2F1 activation results in the transcriptional upregulation of critical pro-apoptotic genes, such as Bik and Bim, and the transcriptional repression of distinct anti-apoptotic family members, including $\mathrm{Bcl}-2$ (82,83,87-91). According to this, and since the exposed to the higher dose of cisplatin RT4 and T24 cells were both characterized by a Bik and Bim strong transactivation response, paralleled with a severe downregulation of $\mathrm{Bcl}-2$ gene (Fig. 6), E2F1 might be critically involved in the cisplatin-mediated apoptosis of bladder cancer cells and, likely, in a p53-independent manner. It seems that both grade I (RT4) and grade III (T24) cell types could undergo cisplatin-induced apoptosis through an E2F1-mediated functional perturbation of the intracellular balance between certain pro-apoptotic (i.e., Bik and Bim) and anti-apoptotic (i.e., Bcl-2) components (83). As a consequence, mitochondrial permeability should be increased, allowing the leakage of, among others, the pro-apoptotic molecule Cytochrome c into the cytosol, whereat it could induce the apoptosome formation, maturation of Caspase repertoire and eventually activation of apoptosis $(12,26,31,47)$. Thereby, for cisplatin to operate as an apoptotic inducer in bladder cancer cells, the intrinsic mitochondrial pathway seems to be absolutely required and, moreover, its functional potency must be partly regulated in a p53-independent manner. Interestingly, $\mathrm{Bcl}-2$ was found to be frequently overexpressed in a variety of human cancers $(12,47,80)$, while the acquisition of resistance to cisplatin in a T24-derived subclone (T24R2) was previously associated with a strong upregulation of $\mathrm{Bcl}-2$ protein levels (92). Moreover, in human lung cancer H460 cells exposed to cisplatin, Bcl-2 protein was shown to be downregulated through a dephosphorylation and ubiquitination process, targeting its degradation by proteasome $(27,93)$.

Contrary to E2F1, the p53-dependent transactivation patterns can be functionally coupled to the differential sensitivity of RT4 and T24 cells to cisplatin exposure. Distinct p53 target genes, such as Fas, FasL, Puma and Caspase-10, $(15,34-37,94)$ were transcriptionally upregulated after drug treatment in the p53-proficient RT4 cells, but not in the p53-deficient T24 cells (Fig. 7), whereas both Bax and Noxa (other p53 targets) gene activities in response to the drug remained unaffected (data not shown), thereby allowing the association of T24 relative resistance to cisplatin toxicity with certain p53 target gene product cellular activities. It seems that the presence of a functional wild-type p53 is tightly linked to the efficient induction of the Fas/FasL-mediated apoptosis in bladder cancer cells after cisplatin administration. Indeed, Fas and FasL cell surface expression can be strongly upregulated after exposure of several cancer cell lines carrying wild-type p53 to cisplatin $(33,95)$, whereas mutant p53 can function as a potent repressor of Fas gene activity $(95,96)$, thus providing p53-deficient or p53-null cells with the advantage of chemoresistance. As previously suggested, the chemosensitivity of solid tumor cells depends on intact apoptotic pathways, involving engagement of the Fas/FasL system and processing of the cognate Caspases $(6,97)$. Thereafter, the relative resistance of $\mathrm{T} 24$ cells to cisplatin activity could evolve through a p53-dependent functional attenuation of the Fas/FasL signaling pathway, a scenario that is strongly supported by the absence of a mature and fully active Caspase- 8 (since having missed the small cleaved fragment) in T2 4 cells treated with the higher drug dose (Fig. 2). Interestingly, loss of the Caspase-8 activation pathway has been previously implicated in resistance to cisplatinmediated apoptosis of HEp-2 cells (human laryngeal cancer) (98). The diminished role of Fas/FasL system in cisplatininduced apoptosis has been also suggested before for T24 (92) and Jurkat T (49) cell lines, while null for FADD or Caspase- 8 embryonic fibroblasts demonstrated only a partial role of the membrane death receptor pathway in response to chemotherapeutic agents (47).

Furthermore, the absence of TRAIL gene expression and the relative unresponsiveness of Caspase-10 gene (albeit weakly debilitated) to cisplatin exposure (Fig. 7) indicate that, together with Fas/FasL, the other membrane death receptor system of TRAIL/DR4/DR5/Caspase-8/Caspase-10 should be also functionally attenuated, thus significantly contributing to the T24-specific partial resistance to cisplatin apoptotic activity. Accordingly, T24 cells, when compared to RT4, can exhibit significant levels of resistance to TRAILinduced apoptosis, and, interestingly, in an Akt-dependent manner (99). Even though both DR4 and DR5 genes [whose cognate proteins operate as TRAIL membrane receptors (12)] follow prominent p53-dependent expression profiles upon cisplatin exposure (data not shown), the grade-specific repression of TRAIL gene activity (Fig. 7) ensures the complete hindrance of TRAIL/DR4/DR5 functional engagement in drug-induced apoptosis of T24 cells. TRAIL gene silencing in $\mathrm{T} 24$ cells could be mediated through distinct mechanisms, including grade-dependent transcriptional suppression, DNA methylation and histone deacetylation. Indeed, TRAIL is classified among the typical FOXO family member target genes (39), whose transcriptional activities are negatively regulated by, among others, an Akt-mediated phosphorylation mechanism (100-102). Therefore, the constitutively active Akt form, exclusively observed in T24 cells (Fig. 4), could specifically phosphorylate distinct FOXO transcription factors, rendering them inactive to downstream upregule their target gene TRAIL. Nevertheless, $T R A I L$ gene activity can be restored in certain cellular cancer model systems by either 5-Aza-2'-deoxycytidine or HDAC (histone deacetylase) inhibitors, clearly demonstrating the critical role of DNA demethylation and/or histone acetylation, respectively, in apoptotic gene regulation $(12,103,104)$. Our findings likely open a new therapeutic avenue to introducing highly efficient apoptosis in p53-mutated malignant cancers, such as bladder cancer, by targeted overexpression and constitutive activation of the Fas, FasL and TRAIL apoptotic regulators, only in the tumor area (37).

The p53-dependent expression profile of Puma gene (Fig. 7) strongly supports the implication of its cognate protein product in the acquisition process of RT4 and T24 differential resistance to cisplatin activity. Puma, a bona fide 
p53 target gene $(34,35)$, has been previously associated with cisplatin-mediated nephrotoxicity and renal tubular cell apoptosis through an activated p53-specific mechanism (15, 36). Thereby, in contrast to $\mathrm{T} 24$, the putative upregulation and mitochondrial accumulation of Puma, BH3-only, protein in cisplatin-treated RT4 cells could result in a severe neutralization of the Bcl-2 family-based anti-apoptotic functions and a Bax-mediated release of Cytochrome c into the cytosol, followed by Caspase maturation and activation of apoptosis, as previously demonstrated for other cellular systems $(15,26,31)$. Conclusively, a Puma-induced oversensitization of the intrinsic mitochondrial pathway might also critically contribute to the reduced resistance of RT4 cells to cisplatin toxicity.

The group of genes presenting a p53-independent downregulation of the respective transcriptional activities in response to cisplatin contains, besides $B c l-2$, the $F A P-1, A T P 7 A, A T P 7 B$ and $M R P 1$ distinct members. $F A P-1$ expression levels were significantly attenuated in both RT4 and T24 cell lines upon exposure to the higher drug dose (Fig. 6), presumably implying a potential role of FAP-1 protein in cisplatin-induced bladder cancer cell apoptosis. However, this could more likely apply to RT4 and not to T24 cells, since their differential Fas/FasL activation dynamics critically determines the functional importance of the cognate downstream mediators in apoptotic signaling. FAP-1 overexpression has been reported to inhibit Fas-mediated apoptosis in certain human malignant cells, by acting as a negative switch in the Fas/FasL pathway, thereby providing them with a marked survival advantage (32,33). Moreover, silencing of FAP-1 gene expression or inhibition of FAP-1 protein tyrosine phosphatase (PTP) activity could abolish tumor cell resistance to Fas-induced apoptosis in a head and neck cancer model system (SCCHN cells) (105). In contrast, FADD protein, another critical component that positively regulates the Fas/FasL apoptotic potency (intermediates between the activated Fas and immature Caspase-8) (12,26,33), might not essentially contribute to cisplatin-induced apoptosis of RT4 and T24 cells, since the corresponding $F A D D$ gene activities in response to the drug remained unaffected in both cell types examined (data not shown).

The ATP7A, ATP7B and CTR1 gene products serve as direct links between the management of copper homeostasis and effective concentration of cisplatin in a cell (6-8). CTR1, the major copper influx transporter, has been convincingly demonstrated to carry cisplatin and its analogues inside the cell, whereas the ATP7A and ATP7B copper efflux ATPase pumps critically regulate cisplatin export $(6-8,42-44)$. Thus, it is the uptake-efflux relative kinetics that controls intracellular accumulation of cisplatin and, therefore, its cytotoxic action. Loss of CTR1 function results in reduced amount of cisplatin entering cells and, consequently, acquisition of drug resistance (6-8,42,44,106-108). However, CTR1 overexpression could not significantly alter the sensitivity of ovarian carcinoma cells to cisplatin, in spite of the increase in drug accumulation levels $(6,42,109)$. On the other hand, enhanced expression of ATP7A and ATP7B efflux proteins has been positively associated with the degree of cisplatin resistance in tumor cell lines and clinical specimens $(6-8,42,44,110,111)$. ATP7A and ATP7B seem to display distinct and quite different functional properties. Although ATP7B upregulation is linked to a reduced capacity of cells to accumulate cisplatin by virtue of a higher efflux rate, ATP7A overexpression in ovarian carcinoma cells renders them resistant to cisplatin due to increased sequestration of the drug into the vesicular fraction, thus keeping it away from the target sites of its cytotoxic action (7,8,42,111-113).

Treatment of RT4 and T24 cells with the higher dose of cisplatin resulted in a notable reduction of both $A T P 7 A$ and $A T P 7 B$ expression levels, whereas $C T R 1$ gene activity remained unaffected in the two cell lines examined (Fig. 8). Thus, it seems that bladder cancer cell sensitivity to cisplatin can be also derived by critically modulating efflux, but not import, rates of the drug. However, the p53-independent transcriptional attenuation of the $A T P 7 A$ and $A T P 7 B$ genes is not able to account for the differential resistance of RT4 and T24 cells to cisplatin, thus likely incriminating other levels of regulation, such as a malignancy grade-specific localization of the ATP7A and ATP7B transport proteins in distinct subcellular compartments, as it has been recently reported for ovarian carcinoma cells (114).

In addition to the copper transporters, certain multidrug resistant protein (MRP) family members are thought to operate as ATP-dependent exporter pumps for a variety of drugs, including cisplatin $(7,8,45)$. Although MRP1 has been previously demonstrated to confer resistance to anthracyclines, but not cisplatin $(44,45,115)$, the p53-independent downregulation of its respective gene activities in RT4 and T24 cells upon drug exposure strongly suggests a role in bladder cancer cell sensitivity to cisplatin (Fig. 8). In contrast, the expression profile of $M R P 2$ (ABCC2/cMOAT) gene, whose upregulated function is frequently implicated in the development of resistance to cisplatin $(6,7,44,45,115)$, did not seem to be affected by the drug administration in either cell type (data not shown), thus likely dissociating its engagement from cisplatin-mediated toxicity and apoptotic death of human bladder cancer cells.

Our study has tried to unveil the complexity of functional interactions that critically regulate the sensitivity and differential resistance of the human bladder cancer cells RT4 and T24 to the cytotoxic activity of cisplatin, one of the most potent chemotherapeutic agents in clinical practice (Fig. 9). We clearly show that both cell types undergo cisplatin-induced apoptosis through a Caspase-dependent manner. The gradespecific sensitivity to the drug is associated with the differential phosphorylation and activation status of p53 and Akt apoptosis regulators, together with the distinct structural integrity of XIAP and Hsp90 signaling components. Moreover, cisplatin promotes a re-deployment of the transcriptional profiles of several genes that are involved either in apoptosis or in cellular accumulation of the drug. One group could be regulated in an E2F1-dependent manner, while the p53 transcription factor is likely responsible for the transcriptional responses of other examined genes to cisplatin exposure. The detrimental effects of cisplatin must be also linked to an increased accumulation of the drug inside bladder cancer cells, likely due to a severe attenuation of the cisplatin efflux system(s). Interestingly, the majority of the genes of the present study, such as Bik, Bim, Bcl-2, FAP-1, Fas, FasL, TRAIL (only for grade I tumors), Puma, Caspase-10, ATP7A, ATP7B and MRP1, could be used as 
in vivo biomarkers in order to develop a molecular platform that could reliably monitor the responses of human bladder cancer cell populations to cisplatin therapeutic actions, thereby providing clinical protocols with novel and powerful genetic tools for a more efficient and successful management of human urothelial malignancies.

\section{Acknowledgements}

E.G. Konstantakou is a scholarship recipient of the Hellenic State Scholarships Foundation (IKY) (Ph.D. fellowship). P.K. Karkoulis is financially supported by a fellowship awarded from the Institute of Biology, NCSR 'Demokritos', Athens, Greece (Ph.D. fellowship) (Ministry of Development). D.J. Stravopodis would like to devote the present article to the memory of his cousins Dena and Leo Lauren.

\section{References}

1. Zieger K: High throughput molecular diagnostics in bladder cancer - on the brink of clinical utility. Mol Oncol 1: 384-394, 2008 .

2. Clark PE: Bladder cancer. Curr Opin Oncol 19: 241-247, 2007.

3. Cote RJ and Datar RH: Therapeutic approaches to bladder cancer: identifying targets and mechanisms. Crit Rev Oncol Hematol 46 (Suppl.): S67-S83, 2003.

4. Chester JD, Hall GD, Forster M and Protheroe AS: Systemic chemotherapy for patients with bladder cancer - current controversies and future directions. Cancer Treat Rev 30: 343-358, 2004.

5. Perabo FG and Muller SC: New agents for treatment of advanced transitional cell carcinoma. Ann Oncol 18: 835-843, 2007.

6. Wang D and Lippard SJ: Cellular processing of platinum anticancer drugs. Nat Rev Drug Discov 4: 307-320, 2005.

7. Rabik CA and Dolan ME: Molecular mechanisms of resistance and toxicity associated with platinating agents. Cancer Treat Rev 33: 9-23, 2007.

8. Kelland L: The resurgence of platinum-based cancer chemotherapy. Nat Rev Cancer 7: 573-584, 2007.

9. Ho YP, Au-Yeung SC and To KK: Platinum-based anticancer agents: innovative design strategies and biological perspectives. Med Res Rev 23: 633-655, 2003.

10. Zorbas H and Keppler BK: Cisplatin damage: are DNA repair proteins saviors or traitors to the cell? Chembiochem 6 : 1157-1166, 2005.

11. Siddik ZH: Cisplatin: mode of cytotoxic action and molecular basis of resistance. Oncogene 22: 7265-7279, 2003.

12. Meng XW, Lee SH and Kaufmann SH: Apoptosis in the treatment of cancer: a promise kept? Curr Opin Cell Biol 18 668-676, 2006.

13. Mujoo K, Watanabe M, Nakamura J, Khokhar AR and Siddik ZH: Status of p53 phosphorylation and function in sensitive and resistant human cancer models exposed to platinum-based DNA damaging agents. J Cancer Res Clin Oncol 129: 709-718, 2003.

14. Fraser M, Leung BM, Yan X, Dan HC, Cheng JQ and Tsang BK: p53 is a determinant of X-linked inhibitor of apoptosis protein/ Akt-mediated chemoresistance in human ovarian cancer cells. Cancer Res 63: 7081-7088, 2003.

15. Pabla N, Huang S, Mi QS, Daniel R and Dong Z: ATR-Chk2 signaling in p53 activation and DNA damage response during cisplatin-induced apoptosis. J Biol Chem 283: 6572-6583, 2008.

16. Dan HC, Sun M, Kaneko S, Feldman RI, Nicosia SV, Wang HG, Tsang BK and Cheng JQ: Akt phosphorylation and stabilization of X-linked inhibitor of apoptosis protein (XIAP). J Biol Chem 279: 5405-5412, 2004.

17. Yang X, Fraser M, Moll UM, Basak A and Tsang BK: Aktmediated cisplatin resistance in ovarian cancer: modulation of p53 action on caspase-dependent mitochondrial death pathway. Cancer Res 66: 3126-3136, 2006

18. Fraser M, Bai T and Tsang BK: Akt promotes cisplatin resistance in human ovarian cancer cells through inhibition of p53 phosphorylation and nuclear function. Int J Cancer 122: 534-546, 2008.
19. Yang X, Fraser M, Abedini MR, Bai T and Tsang BK: Regulation of apoptosis-inducing factor-mediated, cisplatin-induced apoptosis by Akt. Br J Cancer 98: 803-808, 2008.

20. Mitra AP, Birkhahn M and Cote RJ: p53 and retinoblastoma pathways in bladder cancer. World J Urol 25: 563-571, 2007.

21. Cooper MJ, Haluschak JJ, Johnson D, Schwartz S, Morrison LJ, Lippa M, Hatzivassiliou G and Tan J: p53 mutations in bladder carcinoma cell lines. Oncol Res 6: 569-579, 1994.

22. Hinata N, Shirakawa T, Zhang Z, Matsumoto A, Fujisawa M, Okada H, Kamidono S and Gotoh A: Radiation induces p53dependent cell apoptosis in bladder cancer cells with wild-typep53 but not in p53-mutated bladder cancer cells. Urol Res 31: 387-396, 2003.

23. Mosmann T: Rapid colorimetric assay for cellular growth and survival: application to proliferation and cytotoxicity assays. J Immunol Methods 65: 55-63, 1983

24. Wang D, Stravopodis D, Teglund S, Kitazawa J and Ihle JN: Naturally occurring dominant negative variants of Stat5. Mol Cell Biol 16: 6141-6148, 1996.

25. Sambrook J, Fritsch E and Maniatis T: Molecular Cloning: A Laboratory Manual. 2nd edition. Cold Spring Harbor Laboratory Press, New York, 1989.

26. Fadeel B, Ottosson A and Pervaiz S: Big wheel keeps on turning: apoptosome regulation and its role in chemoresistance. Cell Death Differ 15: 443-452, 2008.

27. Smith L, Lind MJ, Drew PJ and Cawkwell L: The putative roles of the ubiquitin/proteasome pathway in resistance to anticancer therapy. Eur J Cancer 43: 2330-2338, 2007.

28. Stravopodis DJ, Margaritis LH and Voutsinas GE: Drug-mediated targeted disruption of multiple protein activities through functional inhibition of the Hsp90 chaperone complex. Curr Med Chem 14: 3122-3138, 2007.

29. Whitesell L and Lindquist SL: HSP90 and the chaperoning of cancer. Nat Rev Cancer 5: 761-772, 2005.

30. Hostetter DR, Loeb CR, Chu F and Craik CS: Hip is a prosurvival substrate of granzyme B. J Biol Chem 282: 27865-27874, 2007.

31. Willis SN and Adams JM: Life in the balance: how BH3-only proteins induce apoptosis. Curr Opin Cell Biol 17: 617-625, 2005.

32. Abaan OD and Toretsky JA: PTPL1: a large phosphatase with a split personality. Cancer Metastasis Rev 27: 205-214, 2008.

33. Timmer T, De Vries EG and De Jong S: Fas receptor-mediated apoptosis: a clinical application? J Pathol 196: 125-134, 2002.

34. Riley T, Sontag E, Chen P and Levine A: Transcriptional control of human p53-regulated genes. Nat Rev Mol Cell Biol 9: 402-412, 2008.

35. Nakano K and Vousden KH: PUMA, a novel proapoptotic gene, is induced by p53. Mol Cell 7: 683-694, 2001.

36. Tsuruya K, Yotsueda H, Ikeda H, Taniguchi M, Masutani K, Hayashida $\mathrm{H}$, Hirakata $\mathrm{H}$ and Iida $\mathrm{M}$ : Involvement of p53transactivated Puma in cisplatin-induced renal tubular cell death. Life Sci 83: 550-556, 2008.

37. Okazaki T and Sakamuro D: Induction of Fas (CD95/APO-1) ligand is essential for p53-dependent apoptosis in an in vitro renal carcinoma model system. J Cancer Res Clin Oncol 133: 581-588, 2007.

38. Gong B and Almasan A: Genomic organization and transcriptional regulation of human Apo2/TRAIL gene. Biochem Biophys Res Commun 278: 747-752, 2000.

39. Modur V, Nagarajan R, Evers BM and Milbrandt J: FOXO proteins regulate tumor necrosis factor-related apoptosis inducing ligand expression. Implications for PTEN mutation in prostate cancer. J Biol Chem 277: 47928-47937, 2002.

40. Borst P, Jonkers J and Rottenberg S: What makes tumors multidrug resistant? Cell Cycle 6: 2782-2787, 2007.

41. Itamochi $\mathrm{H}$, Kigawa J and Terakawa N: Mechanisms of chemoresistance and poor prognosis in ovarian clear cell carcinoma. Cancer Sci 99: 653-658, 2008.

42. Safaei R: Role of copper transporters in the uptake and efflux of platinum containing drugs. Cancer Lett 234: 34-39, 2006.

43. Lutsenko S, Gupta A, Burkhead JL and Zuzel V: Cellular multitasking: the dual role of human $\mathrm{Cu}$-ATPases in cofactor delivery and intracellular copper balance. Arch Biochem Biophys 476: 22-32, 2008.

44. Kuo MT, Chen HH, Song IS, Savaraj N and Ishikawa T: The roles of copper transporters in cisplatin resistance. Cancer Metastasis Rev 26: 71-83, 2007.

45. Coley HM: Mechanisms and strategies to overcome chemotherapy resistance in metastatic breast cancer. Cancer Treat Rev 34: 378-390, 2008. 
46. Borst P, Rottenberg S and Jonkers J: How do real tumors become resistant to cisplatin? Cell Cycle 7: 1353-1359, 2008.

47. Pommier Y, Sordet O, Antony S, Hayward RL and Kohn KW: Apoptosis defects and chemotherapy resistance: molecular interaction maps and networks. Oncogene 23: 2934-2949, 2004.

48. Stordal B and Davey M: Understanding cisplatin resistance using cellular models. IUBMB Life 59: 696-699, 2007.

49. Wang P, Song JH, Song DK, Zhang J and Hao C: Role of death receptor and mitochondrial pathways in conventional chemotherapy drug induction of apoptosis. Cell Signal 18: 1528-1535, 2006.

50. Blanc C, Deveraux QL, Krajewski S, Janicke RU, Porter AG, Reed JC, Jaggi R and Marti A: Caspase-3 is essential for procaspase-9 processing and cisplatin-induced apoptosis of MCF-7 breast cancer cells. Cancer Res 60: 4386-4390, 2000.

51. Seki K, Yoshikawa H, Shiiki K, Hamada Y, Akamatsu N and Tasaka K: Cisplatin (CDDP) specifically induces apoptosis via sequential activation of caspase-8, -3 and -6 in osteosarcoma. Cancer Chemother Pharmacol 45: 199-206, 2000.

52. Henkels KM and Turchi JJ: Cisplatin-induced apoptosis proceeds by caspase-3-dependent and -independent pathways in cisplatinresistant and -sensitive human ovarian cancer cell lines. Cancer Res 59: 3077-3083, 1999.

53. Cummings BS and Schnellmann RG: Cisplatin-induced renal cell apoptosis: caspase 3-dependent and -independent pathways. J Pharmacol Exp Ther 302: 8-17, 2002.

54. Oren M: Decision making by p53: life, death and cancer. Cell Death Differ 10: 431-442, 2003

55. Vekris A, Meynard D, Haaz MC, Bayssas M, Bonnet J and Robert J: Molecular determinants of the cytotoxicity of platinum compounds: the contribution of in silico research. Cancer Res 64: 356-362, 2004

56. Perego P, Giarola M, Righetti SC, Supino R, Caserini C, Delia D, Pierotti MA, Miyashita T, Reed JC and Zunino F: Association between cisplatin resistance and mutation of p53 gene and reduced bax expression in ovarian carcinoma cell systems. Cancer Res 56: 556-562, 1996.

57. Kanamori Y, Kigawa J, Minagawa Y, Irie T, Oishi T, Shimada M, Takahashi M, Nakamura T, Sato K and Terakawa N: A newly developed adenovirus-mediated transfer of a wild-type p53 gene increases sensitivity to cis-diamminedichloroplatinum (II) in $\mathrm{p} 53$ deleted ovarian cancer cells. Eur J Cancer 34: 1802-1806, 1998.

58. Kigawa J, Sato S, Shimada M, Kanamori Y, Itamochi H and Terakawa N: Effect of p53 gene transfer and cisplatin in a peritonitis carcinomatosa model with p53-deficient ovarian cancer cells. Gynecol Oncol 84: 210-215, 2002.

59. Fan J and Bertino JR: Modulation of cisplatinum cytotoxicity by p53: effect of p53-mediated apoptosis and DNA repair. Mol Pharmacol 56: 966-972, 1999.

60. Zamble DB, Jacks T and Lippard SJ: p53-dependent and -independent responses to cisplatin in mouse testicular terato-carcinoma cells. Proc Natl Acad Sci USA 95: 6163-6168, 1998.

61. Ullrich SJ, Sakaguchi K, Lees-Miller SP, Fiscella M, Mercer WE, Anderson CW and Appella E: Phosphorylation at Ser-15 and Ser-392 in mutant p53 molecules from human tumors is altered compared to wild-type p53. Proc Natl Acad Sci USA 90: 5954-5958, 1993.

62. Shieh SY, Ikeda M, Taya Y and Prives C: DNA damageinduced phosphorylation of $\mathrm{p} 53$ alleviates inhibition by MDM2. Cell 91: 325-334, 1997.

63. Shangary S and Wang S: Targeting the MDM2-p53 interaction for cancer therapy. Clin Cancer Res 14: 5318-5324, 2008.

64. Shouse GP, Cai X and Liu X: Serine 15 phosphorylation of p53 directs its interaction with B56gamma and the tumor suppressor activity of B56gamma-specific protein phosphatase 2A. Mol Cell Biol 28: 448-456, 2008.

65. Matsumoto M, Furihata M and Ohtsuki Y: Posttranslational phosphorylation of mutant $\mathrm{p} 53$ protein in tumor development Med Mol Morphol 39: 79-87, 2006.

66. Radhakrishnan SK and Gartel AL: CDK9 phosphorylates p53 on serine residues 33, 315 and 392. Cell Cycle 5: 519-521, 2006.

67. Oster B, Bundgaard B, Hupp TR and Hollsberg P: Human herpesvirus $6 \mathrm{~B}$ induces phosphorylation of $\mathrm{p} 53$ in its regulatory domain by a CK2- and p38-independent pathway. J Gen Virol 89: 87-96, 2008.

68. Nakashio A, Fujita N, Rokudai S, Sato S and Tsuruo T: Prevention of phosphatidylinositol 3'-kinase-Akt survival signaling pathway during topotecan-induced apoptosis. Cancer Res 60: 5303-5309, 2000 .
69. Tang D, Okada H, Ruland J, Liu L, Stambolic V, Mak TW and Ingram AJ: Akt is activated in response to an apoptotic signal. J Biol Chem 276: 30461-30466, 2001.

70. Karpinich NO, Tafani M, Rothman RJ, Russo MA and Farber JL: The course of etoposide-induced apoptosis from damage to DNA and p53 activation to mitochondrial release of cytochrome c. J Biol Chem 277: 16547-16552, 2002.

71. Carpten JD, Faber AL, Horn C, Donoho GP, Briggs SL, Robbins CM, Hostetter G, Boguslawski S, Moses TY, Savage S, Uhlik M, Lin A, Du J, Qian YW, Zeckner DJ, Tucker-Kellogg G, Touchman J, Patel K, Mousses S, Bittner M, Schevitz R, Lai MH, Blanchard KL and Thomas JE: A transforming mutation in the pleckstrin homology domain of AKT1 in cancer. Nature 448: 439-444, 2007.

72. Wu X, Obata T, Khan Q, Highshaw RA, De Vere White R and Sweeney C: The phosphatidylinositol-3 kinase pathway regulates bladder cancer cell invasion. BJU Int 93: 143-150, 2004.

73. Liu J, Babaian DC, Liebert M, Steck PA and Kagan J: Inactivation of MMAC1 in bladder transitional-cell carcinoma cell lines and specimens. Mol Carcinog 29: 143-150, 2000.

74. Cheng JQ, Jiang X, Fraser M, Li M, Dan HC, Sun M and Tsang BK: Role of X-linked inhibitor of apoptosis protein in chemoresistance in ovarian cancer: possible involvement of the phosphoinositide-3 kinase/Akt pathway. Drug Resist Updat 5: 131-146, 2002.

75. Asselin E, Mills GB and Tsang BK: XIAP regulates Akt activity and caspase-3-dependent cleavage during cisplatin-induced apoptosis in human ovarian epithelial cancer cells. Cancer Res 61: 1862-1868, 2001

76. Deveraux QL, Leo E, Stennicke HR, Welsh K, Salvesen GS and Reed JC: Cleavage of human inhibitor of apoptosis protein XIAP results in fragments with distinct specificities for caspases. EMBO J 18: 5242-5251, 1999.

77. Ishida R, Takaoka Y, Yamamoto S, Miyazaki T, Otaka M, Watanabe S, Komatsuda A, Wakui H, Sawada K, Kubota H and Itoh $\mathrm{H}$ : Cisplatin differently affects amino terminal and carboxyl terminal domains of HSP90. FEBS Lett 582: 3879-3883, 2008.

78. Beck R, Verrax J, Gonze T, Zappone M, Pedrosa RC, Taper H, Feron $\mathrm{O}$ and Calderon PB: Hsp90 cleavage by an oxidative stress leads to its client proteins degradation and cancer cell death. Biochem Pharmacol 77: 375-383, 2009.

79. Shen SC, Yang LY, Lin HY, Wu CY, Su TH and Chen YC: Reactive oxygen species-dependent HSP90 protein cleavage participates in arsenical As(+3)- and MMA(+3)-induced apoptosis through inhibition of telomerase activity via JNK activation. Toxicol Appl Pharmacol 229: 239-251, 2008

80. Stravopodis DJ, Karkoulis PK, Konstantakou EG, Melachroinou S, Lampidonis AD, Anastasiou D, Kachrilas S, Messini-Nikolaki N, Papassideri IS, Aravantinos G, Margaritis LH and Voutsinas GE: Grade-dependent effects on cell cycle progression and apoptosis in response to doxorubicin in human bladder cancer cell lines. Int J Oncol 34: 137-160, 2009.

81. Meslin F, Thiery J, Richon C, Jalil A and Chouaib S: Granzyme B-induced cell death involves induction of p53 tumor suppressor gene and its activation in tumor target cells. J Biol Chem 282: 32991-32999, 2007.

82. Stanelle J and Putzer BM: E2F1-induced apoptosis: turning killers into therapeutics. Trends Mol Med 12: 177-185, 2006.

83. Putzer BM: E2F1 death pathways as targets for cancer therapy. J Cell Mol Med 11: 239-251, 2007.

84. Lin WC, Lin FT and Nevins JR: Selective induction of E2F1 in response to DNA damage, mediated by ATM-dependent phosphorylation. Genes Dev 15: 1833-1844, 2001.

85. Yu F, Megyesi J, Safirstein RL and Price PM: Involvement of the CDK2-E2F1 pathway in cisplatin cytotoxicity in vitro and in vivo. Am J Physiol Renal Physiol 293: F52-F59, 2007.

86. Ianari A, Gallo R, Palma M, Alesse E and Gulino A: Specific role for $\mathrm{p} 300 / \mathrm{CREB}$-binding protein-associated factor activity in E2F1 stabilization in response to DNA damage. J Biol Chem 279: 30830-30835, 2004

87. Real PJ, Sanz C, Gutierrez O, Pipaon C, Zubiaga AM and Fernandez-Luna JL: Transcriptional activation of the proapoptotic bik gene by E2F proteins in cancer cells. FEBS Lett 580: 5905-5909, 2006

88. Hershko T and Ginsberg D: Up-regulation of Bcl-2 homology 3 (BH3)-only proteins by E2F1 mediates apoptosis. J Biol Chem 279: 8627-8634, 2004. 
89. Gaviraghi M, Caricasole A, Costanzo C, Diamanti D, Dandrea M, Donadelli M, Scarpa A and Palmieri M: Identification of a candidate alternative promoter region of the human Bcl2L11 (Bim) gene. BMC Mol Biol 9: 56, 2008.

90. Biswas SC, Liu DX and Greene LA: Bim is a direct target of a neuronal E2F-dependent apoptotic pathway. J Neurosci 25: 8349-8358, 2005.

91. Eischen CM, Packham G, Nip J, Fee BE, Hiebert SW, Zambetti GP and Cleveland JL: Bcl-2 is an apoptotic target suppressed by both c-Myc and E2F-1. Oncogene 20: 6983-6993, 2001

92. Cho HJ, Kim JK, Kim KD, Yoon HK, Cho MY, Park YP, Jeon JH, Lee ES, Byun SS, Lim HM, Song EY, Lim JS, Yoon DY, Lee HG and Choe YK: Upregulation of Bcl-2 is associated with cisplatin-resistance via inhibition of Bax translocation in human bladder cancer cells. Cancer Lett 237: 56-66, 2006.

93. Wang L, Chanvorachote P, Toledo D, Stehlik C, Mercer RR, Castranova V and Rojanasakul Y: Peroxide is a key mediator of Bcl-2 down-regulation and apoptosis induction by cisplatin in human lung cancer cells. Mol Pharmacol 73: 119-127, 2008.

94. Jiang M, Wei Q, Wang J, Du Q, Yu J, Zhang L and Dong Z: Regulation of PUMA-alpha by p53 in cisplatin-induced renal cell apoptosis. Oncogene 25: 4056-4066, 2006.

95. Muller M, Wilder S, Bannasch D, Israeli D, Lehlbach K, Li-Weber M, Friedman SL, Galle PR, Stremmel W, Oren M and Krammer PH: p53 activates the CD95 (APO-1/Fas) gene in response to DNA damage by anticancer drugs. J Exp Med 188: 2033-2045, 1998.

96. Zalcenstein A, Stambolsky P, Weisz L, Muller M, Wallach D, Goncharov TM, Krammer PH, Rotter V and Oren M: Mutant p53 gain of function: repression of CD95(Fas/APO-1) gene expression by tumor-associated p53 mutants. Oncogene 22: $5667-5676,2003$.

97. Fulda S, Los M, Friesen C and Debatin KM: Chemosensitivity of solid tumor cells in vitro is related to activation of the CD95 system. Int J Cancer 76: 105-114, 1998.

98. Toyozumi Y, Arima N, Izumaru S, Kato S, Morimatsu M and Nakashima T: Loss of caspase- 8 activation pathway is a possible mechanism for CDDP resistance in human laryngeal squamous cell carcinoma, HEp-2 cells. Int J Oncol 25: 721-728, 2004

99. Oka N, Tanimoto S, Taue R, Nakatsuji H, Kishimoto T, Izaki H, Fukumori T, Takahashi M, Nishitani M and Kanayama HO: Role of phosphatidylinositol-3 kinase/Akt pathway in bladder cancer cell apoptosis induced by tumor necrosis factor-related apoptosis-inducing ligand. Cancer Sci 97: 1093-1098, 2006.

100. Burgering BM and Medema RH: Decisions on life and death: FOXO Forkhead transcription factors are in command when PKB/Akt is off duty. J Leukoc Biol 73: 689-701, 2003.

101. Greer EL and Brunet A: FOXO transcription factors at the interface between longevity and tumor suppression. Oncogene 24: 7410-7425, 2005.

102. Lam EW, Francis RE and Petkovic M: FOXO transcription factors: key regulators of cell fate. Biochem Soc Trans 34: 722-726, 2006.
103. Nebbioso A, Clarke N, Voltz E, Germain E, Ambrosino C, Bontempo P, Alvarez R, Schiavone EM, Ferrara F, Bresciani F, Weisz A, De Lera AR, Gronemeyer H and Altucci L: Tumorselective action of HDAC inhibitors involves TRAIL induction in acute myeloid leukemia cells. Nat Med 11: 77-84, 2005.

104. Xu J, Zhou JY, Tainsky MA and Wu GS: Evidence that tumor necrosis factor-related apoptosis-inducing ligand induction by 5-Aza-2'-deoxycytidine sensitizes human breast cancer cells to adriamycin. Cancer Res 67: 1203-1211, 2007.

105. Wieckowski E, Atarashi Y, Stanson J, Sato TA and Whiteside TL: FAP-1-mediated activation of NF-kappaB induces resistance of head and neck cancer to Fas-induced apoptosis. J Cell Biochem 100: 16-28, 2007.

106. Ishida S, Lee J, Thiele DJ and Herskowitz I: Uptake of the anticancer drug cisplatin mediated by the copper transporter Ctr1 in yeast and mammals. Proc Natl Acad Sci USA 99: 14298-14302, 2002

107. Holzer AK, Manorek GH and Howell SB: Contribution of the major copper influx transporter CTR 1 to the cellular accumulation of cisplatin, carboplatin, and oxaliplatin. Mol Pharmacol 70: 1390-1394, 2006.

108. Song IS, Savaraj N, Siddik ZH, Liu P, Wei Y, Wu CJ and Kuo MT: Role of human copper transporter Ctr 1 in the transport of platinum-based antitumor agents in cisplatinsensitive and cisplatin-resistant cells. Mol Cancer Ther 3: 1543-1549, 2004.

109. Holzer AK, Samimi G, Katano K, Naerdemann W, Lin X, Safaei R and Howell SB: The copper influx transporter human copper transport protein 1 regulates the uptake of cisplatin in human ovarian carcinoma cells. Mol Pharmacol 66: 817-823, 2004.

110. Safaei R, Holzer AK, Katano K, Samimi G and Howell SB: The role of copper transporters in the development of resistance to Pt drugs. J Inorg Biochem 98: 1607-1613, 2004.

111. Komatsu M, Sumizawa T, Mutoh M, Chen ZS, Terada K, Furukawa T, Yang XL, Gao H, Miura N, Sugiyama T and Akiyama S: Copper-transporting P-type adenosine triphosphatase (ATP7B) is associated with cisplatin resistance. Cancer Res 60: 1312-1316, 2000.

112. Nakayama K, Miyazaki K, Kanzaki A, Fukumoto M and Takebayashi Y: Expression and cisplatin sensitivity of coppertransporting P-type adenosine triphosphatase (ATP7B) in human solid carcinoma cell lines. Oncol Rep 8: 1285-1287, 2001.

113. Samimi G, Safaei R, Katano K, Holzer AK, Rochdi M, Tomioka $M$, Goodman $M$ and Howell SB: Increased expression of the copper efflux transporter ATP7A mediates resistance to cisplatin, carboplatin, and oxaliplatin in ovarian cancer cells. Clin Cancer Res 10: 4661-4669, 2004.

114. Kalayda GV, Wagner CH, Buss I, Reedijk J and Jaehde U: Altered localisation of the copper efflux transporters ATP7A and ATP7B associated with cisplatin resistance in human ovarian carcinoma cells. BMC Cancer 8: 175, 2008.

115. Borst P, Evers R, Kool M and Wijnholds J: A family of drug transporters: the multidrug resistance-associated proteins. J Natl Cancer Inst 92: 1295-1302, 2000. 